\title{
37. DIAGENESIS OF SILICEOUS PARTICLES IN SUBANTARCTIC SEDIMENTS, HOLE 699A: POSSIBLE MICROBIAL MEDIATION ${ }^{1}$
}

\author{
Claude L. V. Monty, ${ }^{2}$ Frances Westall, ${ }^{3}$ and Sjierk van der Gaast ${ }^{4}$ \\ "In view of this high abundance of silicate minerals in the near-surface crustal regime, it is perhaps not \\ surprising that organisms ... have found numerous ways of interacting with siliceous materials"'
}

(Heinen and Oehler, 1979).

\begin{abstract}
A number of neogenic opaline structures, not previously reported in the literature, as well as other neogenic phases are described from four Oligocene to Pliocene biosiliceous sediment samples from Hole 699A. The possible influence of microbes on the formation or the morphology of some of them is discussed. The samples, which are early Pliocene, early to middle Miocene, and late Oligocene (two) in age, were histologically fixed aboard ship upon retrieval.

Investigations of the samples used SEM (with Edax/Tracor) and XRD methods. Diagenesis has affected all four samples, but the most extensive development of neoformed structures occurs in the Miocene and uppermost Oligocene samples, where microbial filaments ( 0.05 to $10 \mu \mathrm{m}$ long), microbial colonies, and siliceous microhemispheroids ( 0.2 to $0.7 \mu \mathrm{m}$ diameter) were observed. The latter encrust filaments, diatoms, and detrital grains to varying degrees. Other neoformed structures include (1) flakes formed by coalesced microhemispheroids, some of which are guided by short, stubby filaments, which occur only in the Miocene and uppermost Oligocene samples, and (2) flakes characterized by smooth or microfissured surfaces, which grow on diatom frustules and in pore spaces and have a more widespread distribution. The XRD data indicate possible cristobalite formation in the Miocene and uppermost Oligocene samples; we believe that the neoformed opaline structures (encrusted filaments and microhemispheroids) may represent an early phase of opal-CT. The timing of neoformation of most of these features appears to have been fairly recent, continuing even at the time of sampling.

There appears to be no direct correlation of this incipient, lower Miocene-uppermost Oligocene diagenetic layer and the pore-water chemistry profiles; a massive increase in shear strength in these sediments, however, may indicate some cementation.

Smectite was identified by XRD as the most prominent clay mineral in these generally clay-poor sediments. Honeycombed minerals with filamentous edges, which could correspond to smectite, were observed with SEM in the pore spaces.
\end{abstract}

\section{INTRODUCTION}

This chapter is a progress report of a pilot study investigating microbial mediation in the diagenesis of biosiliceous and aluminosilicate particles in marine sediments.

The diagenesis of silica is a widely studied subject that has received a considerable amount of attention especially because of the Deep Sea Drilling Project and Ocean Drilling Program (ODP). This has resulted in the generation of an enormous amount of literature, in which extensive discussion has brought much understanding to the problems of silica diagenesis in terms of thermodynamic and physicochemical processes (e.g., Wise and Hsü, 1971; Froelich, 1974; Calvert, 1974; Flörke et al., 1975, 1976; Kastner et al., 1977; von Rad et al., 1977; Hein et al., 1978; Riech and von Rad, 1979; Kastner, 1981; Kastner and Gieskes, 1983; Williams et al., 1985; Williams and Crerar, 1985, to name but a few). However, the study of carbonates by one of the authors (C. M.) has revealed the extensive impact of microbial activity on carbonate neogenesis and diagenesis as well as on the deposition of phosphate, metal oxides, sulfides, etc., which is presently well known. There is, therefore, a

\footnotetext{
${ }^{1}$ Ciesielski, P. F., Kristoffersen, Y., et al., 1991. Proc. ODP, Sci. Results, 114: College Station, TX (Ocean Drilling Program).

2 Université de Nantes, Laboratoire de Biosédimentologie, 44072 Nantes Cédex 03, France, and Université de Liège, 4000 Liège, Belgium.

${ }^{3}$ Alfred Wegener Institute, Columbus Strasse, D-2850 Bremerhaven, FRG (Present address: Université de Nantes, Laboratoire de Biosédimentologie, 44072 Nantes Cédex 03, France).

${ }^{4}$ Netherlands Institute of Sea Research, Postbus 59, 1790 AB Den Burg, Texel, The Netherlands.
}

strong possibility that silica diagenesis and neogenesis might also follow what increasingly appears to be a common process. Microbial mediation of silica dissolution and precipitation has already been discussed with respect to soils (Robert and Berthelin, 1986) and extended to more general situations (Krumbein, 1983). This evolution of concepts opened the way to our pilot study. In this chapter we concentrate on the description of neoformed opaline structures not previously reported. Our preliminary interpretations are intended as a cautious introduction to a complex subject and should be taken as such.

\section{BACKGROUND AND MATERIAL}

Hole 699A is in a water depth of $3716 \mathrm{~m}$ in the Southeast Atlantic Ocean (Fig. 1). Six lithostratigraphic units were distinguished in sediments that grade from clayey siliceous oozes through mixed siliceous calcareous oozes down to chalk (Ciesielski, Kristoffersen, et al., 1988). Lithostratigraphic Unit I (0-85.7 $\mathrm{m}$ below seafloor [mbsf]) consists of diatom clay to clayey diatom ooze of latest Oligocene to Pleistocene age. Units II and III (85.7-235.66 mbsf) span the lower Oligocene to lower Miocene and consist of siliceous nannofossil ooze/nannofossil siliceous ooze grading down into nannofossil ooze. Unit IV (235.66-335.45 mbsf) is transitional between siliceous and calcareous lithologies and ranges from late Eocene to early Oligocene in age. Nannofossil chalk and micritic chalk of early Eocene to late Eocene age make up Unit V (335.45-487.91 mbsf). At the bottom of the hole, Unit VI (496.6-516.3 mbsf) is composed of zeolite-bearing claystone and clay-bearing micritic nannofossil chalk of late Paleocene age overlying a 1.8-m-thick gravel and volcanic sand layer. 


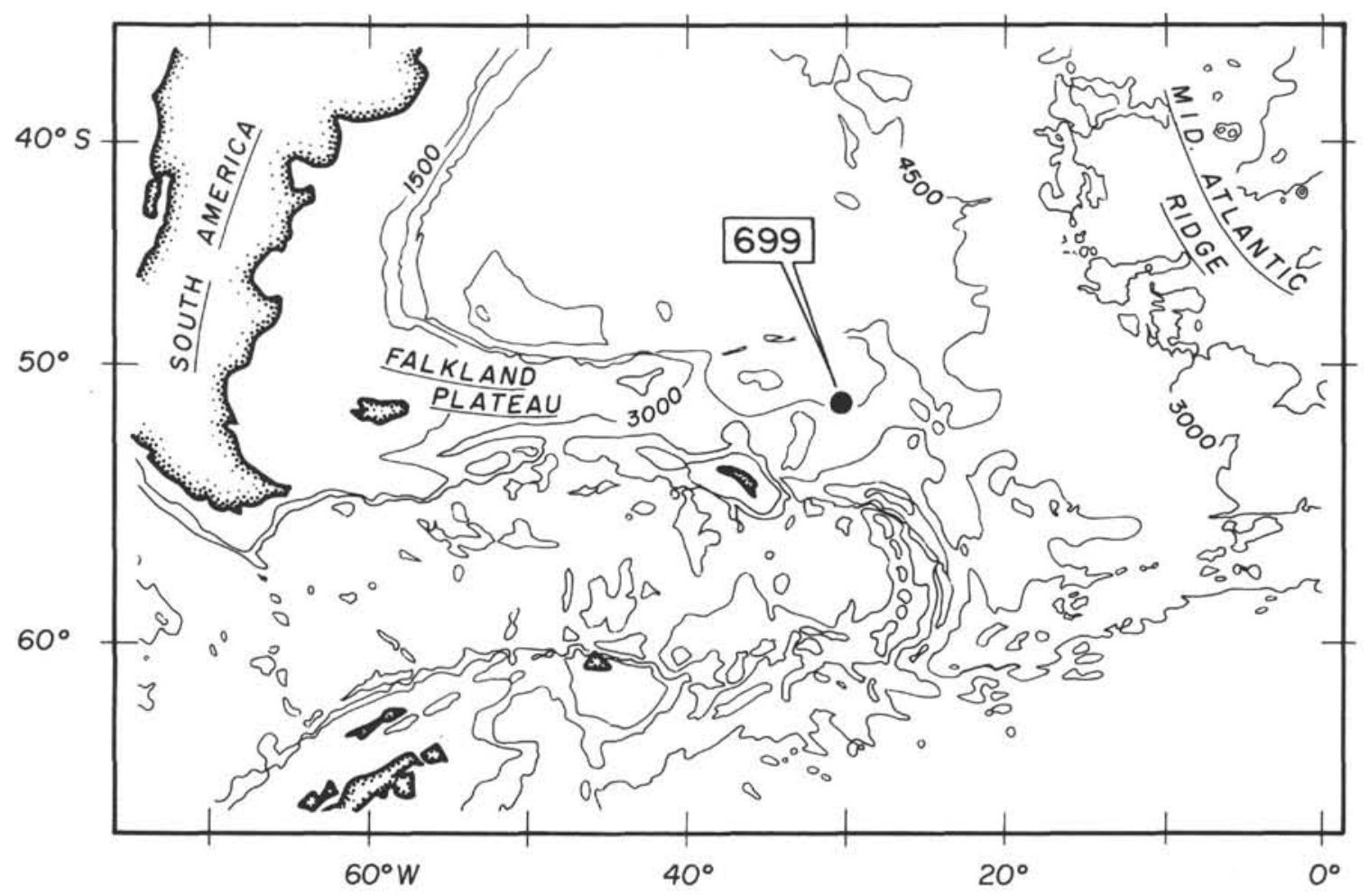

Figure 1. Location of Site 699 in the Southeast Atlantic Ocean.

Our pilot investigation covered samples from three Leg 114 sites $(699,701$, and 704$)$, for which we have more than 500 SEM photographs. In this paper we concentrate on the following samples from Hole 699A:

Sample 114-699A-5H-5, 7-9 cm: 43.17 mbsf, lower Pliocene, detrital/volcanic glass-bearing diatom ooze.

Sample 114-699A-8H-2, 108-110 cm: $68.17 \mathrm{mbsf}$, lower or middle Miocene (within the depth uncertainty of a lower to middle Miocene hiatus at 69.2-67.52 mbsf), detrital/volcanic glass-bearing diatom siliceous ooze.

Sample 114-699A-10H-1, 92-94 cm: 85.7 mbsf, uppermost Oligocene, siliceous-diatom ooze.

Sample 114-699A-18H-5, 36-38 cm: 166.96 mbsf, upper Oligocene (28.15 Ma), diatom-bearing nannofossil ooze.

In addition, Samples 114-699A-8H-2, 115-117 cm, and 114-699A-10H-1, 112-114 cm, were taken in similar diatomsiliceous lithologic intervals close to the Miocene and uppermost Oligocene samples, respectively. These two extra samples were used for X-ray-diffraction (XRD) analysis, as there was not sufficient material remaining for these analyses from the original four histologically preserved samples.

There are a number of hiatuses in the Neogene section of this hole, the most important of which is between the lower Miocene and the upper Miocene (Ciesielski, Kristoffersen, et al., 1988, p. 167). This hiatus represents a particularly long time span (5.5-9.0 Ma). Correlation of the physical properties and stratigraphic data (Ciesielski, Kristoffersen, et al., 1988, p. 190) suggests that the hiatus occurs at a depth of $68 \mathrm{mbsf}$. The steady increase in water content and porosity and decrease in bulk density downward across this horizon imply that it was caused by a lack of sedimentation rather than by the erosion of sediment, which would have resulted in a sharp jump in these parameters. The lack of sediment accumulation is attributed to vigorous bottom-water circulation.
Pore-water data and the physical properties of the sediment in the vicinity of the four samples are listed in Table 1. In the geochemical data from Ciesielski, Kristoffersen, et al. (1988), organic carbon contents are very low, and a measurable amount of $11 \%$ was reached only in Sample 114-699A-10H-1, 92-94 cm. With the exception of the oldest Sample 114-699A$18 \mathrm{H}-5,36-38 \mathrm{~cm}$, which has a carbonate content of $40 \%$, there is no carbonate in these samples. The interstitial-water chemistry in the upper Neogene section does not vary much, although $\mathrm{pH}$, alkalinity, and dissolved silica are slightly lower in the uppermost Sample 114-699A-5H-5, 7-9 cm, whereas $\mathrm{Mg}$ is higher (perhaps reflecting the higher clay content). The oldest Sample 114-699A-18H-5, 36-38 cm, on the other hand, exhibits higher alkalinity, dissolved silica, and $\mathrm{Ca}$ values but lower $\mathrm{Mg}, \mathrm{pH}$, sulfate, and salinity values.

Water content, porosity, and grain density gradually increase with depth and there is a corresponding decrease in both wet- and dry-bulk densities between the uppermost Sample 114-699A-5H-5, 7-9 cm, and the third Sample 114-699A-10 H-1, 92-94 cm. However, the trend is reversed in the lowest sample, which exhibits low water content, porosity, and grain density as well as higher wet- and dry-bulk densities.

\section{METHODS}

Samples were taken aboard ship using a small, $2-\mathrm{cm}^{3}$ plastic box marked with an orientation arrow as soon as possible after the cores had been sectioned and split. All utensils were rinsed with alcohol before use. After retrieval, samples were put into a perspex box containing a $4 \%$ solution of formaldehyde in filtered seawater for 3-4 days, after which they were removed and placed on a perforated plastic tray over a formaldehyde/seawater bath for storage. Throughout storage the $\mathrm{pH}$ of the preserving solution was checked to make sure that it remained at 7.5. 
Table 1. Pore-water chemistry and physical properties, Hole 699A.

\begin{tabular}{lcccl}
\hline & $\begin{array}{l}5 \mathrm{H}-5, \\
7-9 \mathrm{~cm}\end{array}$ & $\begin{array}{l}8 \mathrm{H}-2, \\
108-110 \mathrm{~cm}\end{array}$ & $\begin{array}{l}10 \mathrm{H}-1, \\
92-94 \mathrm{~cm}\end{array}$ & $\begin{array}{l}18 \mathrm{H}-5, \\
36-38 \mathrm{~cm}\end{array}$ \\
\hline Depth (mbsf) & 43.17 & 68.17 & 85.52 & 166.96 \\
Organic carbon (\%) & 0 & 0.04 & 0.11 & 0 \\
Carbonate (\%) & 0.92 & 0.08 & 0.33 & 40 \\
$\mathrm{Ca}(\mathrm{mmol} / \mathrm{L})$ & 15 & 15 & 15 & 26 \\
$\mathrm{Mg}(\mathrm{mmol} / \mathrm{L})$ & 50 & 49 & 47 & 45 \\
$\mathrm{pH}$ & 7.6 & 7.8 & 7.8 & 7.4 \\
Alkalinity (mmol/L) & 3.7 & 4.2 & 4.5 & 4.6 \\
Silica $(\mu \mathrm{mol} / \mathrm{L})$ & 800 & 900 & 900 & 1100 \\
Sulfate $(\mathrm{mmol} / \mathrm{L})$ & 27 & 27 & 27 & 25 \\
Salinity $(\mathrm{ppt})$ & 35.2 & 35 & 35 & 34.8 \\
Water content $(\%)$ & 52 & 57 & 63 & 50 \\
Porosity $(\%)$ & 73.5 & 77 & 84 & 76.3 \\
Wet-bulk density $\left(\mathrm{g} / \mathrm{cm}^{3}\right)$ & 1.47 & 1.53 & 1.36 & 1.57 \\
Dry-bulk density $\left(\mathrm{g} / \mathrm{cm}^{3}\right)$ & 0.72 & 0.68 & 0.5 & 0.79 \\
Grain density $\left(\mathrm{g} / \mathrm{cm}^{3}\right)$ & 2.45 & 2.78 & 2.86 & 2.79 \\
\hline
\end{tabular}

Note: Values interpolated from downhole curves in Ciesielski, Kristoffersen, et al (1988).

Throughout the subsequent laboratory procedures all utensils were cleaned with alcohol immediately before use. The samples were carefully removed from the containers and a slice was cut off, quite close to the outer margin, to ensure that we were subsampling sediment that had been well fixed. Each 1 -mm-thick slice was then dehydrated in a series of alcohol baths of increasing strength for $2 \mathrm{hr}$ at each stage. We used $10 \%, 30 \%, 50 \%, 70 \%, 90 \%$, and two $100 \%$ steps. Finally, each sample was put into an amylacetate bath for $2 \mathrm{hr}$ before being dried with the critical point apparatus to preserve the nannostructures and the morphology of any alcohol-insoluble organic material in the sediment.

In our attempts to break the dried slices to obtain a fracture surface for SEM examination, some of the samples broke into small pieces. We managed to retain oriented slices of Samples $114-699 \mathrm{~A}-8 \mathrm{H}-2,108-110 \mathrm{~cm}$, and 114-699A-10H-1, 92-94 cm. The slices and fragments were mounted on stubs and coated with carbon and then with gold or gold/palladium. The specimens were observed with two electron microscopes, a Philips 515 with Edax analyzer at the Alfred Wegener Institute and a Jeol JSM 35C with Tracor analyzer at the University of Nantes. Many of our observations were made with stereopairs of photographs, which we found essential for structural interpretations. (We have included stereopairs arranged for use with a pocket stereoscope in this chapter.)

Smear slides of each sample were prepared for lithologic studies. Visual estimates of the various components were made using a petrological microscope, and the samples were lithologically named after the method of Dean et al. (1984).

In the pretreatment for XRD analysis, the clay fraction $(<2 \mu \mathrm{m})$ was collected by repeated sedimentation using a centrifuge. Samples 114-699A-8H-2, 115-117 cm, and 114$699 \mathrm{~A}-10 \mathrm{H}-1,112-114 \mathrm{~cm}$, suspended well in distilled water (pH 6.75). The $<2-\mu \mathrm{m}$ fraction was $\mathrm{Ca}$-exchanged with a $1 \mathrm{~N}$ $\mathrm{CaCl}_{2}$ solution, with the excess salt removed by repeated washing with distilled water. Sample 114-699A-8H-2, 115$117 \mathrm{~cm}$, suspended well, but Sample 114-699A-10H-1, 112$114 \mathrm{~cm}$, flocculated slightly. An amount of $1 \%$ (weight) $\mathrm{MoS}_{2}$ was added to this fraction as an internal standard. Oriented samples were obtained by filtering the $<2-\mu \mathrm{m}$ fraction onto polished ceramic tiles under suction. The remaining $>2-\mu \mathrm{m}$ fraction was also $\mathrm{Ca}$-exchanged and excess salt removed by repeated washing with distilled water and finally with ethanol. The samples were dried at $105^{\circ} \mathrm{C}$. Nonoriented mounts were then made by pressing the sample into a depression on a metal specimen holder.

The XRD analyses were carried out using a wide-angle goniometer (Philips PW $1025 / 25^{\circ}$ ) in combination with a long fine-focus X-ray tube $(\mathrm{CoK} \alpha)$, a graphite monochromator, and a vacuum helium device. A self-developed, computer-steered divergence slit system enabled constant irradiation of the sample area independent of the angle of incidence of the X-ray beam and accurate alignment (an improvement of the inctrument used earlier by van der Gaast and Vaars, 1981). For measuring the $<2-\mu \mathrm{m}$ fraction, a $0.1-\mathrm{mm}$-wide receiving slit and a $0.5^{\circ}$ antiscatter slit were used with a counting time of 4 $\mathrm{s} / 0.02^{\circ} 2 \theta$. For the $>2-\mu \mathrm{m}$ fraction, a $0.2-\mathrm{mm}$-wide receiving slit and a $1^{\circ}$ antiscatter slit were used with a counting time of $2 \mathrm{~s} / 0.02^{\circ} 2 \theta$. Diffractograms were recorded from $1^{\circ}$ to $17.5^{\circ} 2 \theta$, and from $3^{\circ}$ to $46^{\circ} 2 \theta$ for the fractions $<2$ and $>2 \mu \mathrm{m}$, respectively. The $<2-\mu \mathrm{m}$ samples were measured at $100 \%$, $50 \%$, and $0 \%$ relative humidity instead of the traditional glycolation, room temperature, and $\mathrm{K}$-saturation treatment. A humidity generator developed by van der Gaast and Vaars (1981) was used for this purpose. This technique resulted in reproducible patterns and facilitated and improved the identification of swelling minerals: smectite can easily be distinguished from vermiculite because at $100 \%$ relative humidity its (001) peak appears at $19.0 \AA$ in the XRD pattern, whereas the vermiculite (001) peak shows up at $15.0 \AA$. Moreover, it is a very useful method if only small amounts of sample are available because all measurements are carried out on the same specimen. The XRD data were stored on floppy disc and subsequently corrected for the Lorenz polarization factor and for the irradiated volume. To avoid errors in interpretation, the patterns of the $<2-\mu \mathrm{m}$ fraction measured at $100 \%, 50 \%$, and $0 \%$ relative humidity were plotted normal to the peak of the internal standard (cf. Van der Gaast et al., 1986).

\section{RESULTS}

\section{Smear Slide Observations}

Data from the smear slide analyses are listed in Table 2. Sample 114-699A-5H-5, 7-9 cm, is a diatom ooze with minor

Table 2. Smear slide analysis, Hole 699A.

\begin{tabular}{|c|c|c|c|c|}
\hline & $\begin{array}{c}5 H-5 \\
7-9 \mathrm{~cm}\end{array}$ & $\begin{array}{c}8 \mathrm{H}-2, \\
108-110 \mathrm{~cm}\end{array}$ & $\begin{array}{c}10 \mathrm{H}-1, \\
92-94 \mathrm{~cm}\end{array}$ & $\begin{array}{c}18 \mathrm{H}-5, \\
36-38 \mathrm{~cm}\end{array}$ \\
\hline Depth (mbsf) & 43.17 & 88.17 & 85.52 & 166.96 \\
\hline Diatoms & 70 & 30 & 45 & 20 \\
\hline Radiolarians & tr & 5 & 5 & 5 \\
\hline Sponge spicules & - & - & 5 & tr \\
\hline Silicoflagellates & tr & tr & tr & tr \\
\hline ather siliceous & - & 55 & 40 & - \\
\hline Nannofossils & - & - & - & 70 \\
\hline Foraminifers & - & - & - & tr \\
\hline $\begin{array}{l}\text { Detrital grains/ } \\
\text { volcanic glass }\end{array}$ & 10 & 10 & tr & - \\
\hline Opaque minerals & tr & tr & - & - \\
\hline Clay & 20 & $\mathrm{tr}$ & 5 & 5 \\
\hline $\begin{array}{l}\text { bLithologic } \\
\text { classification }\end{array}$ & $\begin{array}{l}\text { Detrital/ } \\
\text { volcanic glass } \\
\text { clay-bearing } \\
\text { diatom ooze }\end{array}$ & $\begin{array}{l}\text { Detrital/ } \\
\text { volcanic } \\
\text { glass-bearing } \\
\text { siliceousa } \\
\text { ooze }\end{array}$ & $\begin{array}{l}\text { aSiliceous- } \\
\text { diatom } \\
\text { ooze }\end{array}$ & $\begin{array}{l}\text { Diatom- } \\
\text { bearing } \\
\text { nannofossil } \\
\text { ooze }\end{array}$ \\
\hline
\end{tabular}

${ }_{b}^{\text {a }}$ Minute granular particles $<2-\mu \mathrm{m}$ diameter.

After Dean et al. (1984). 

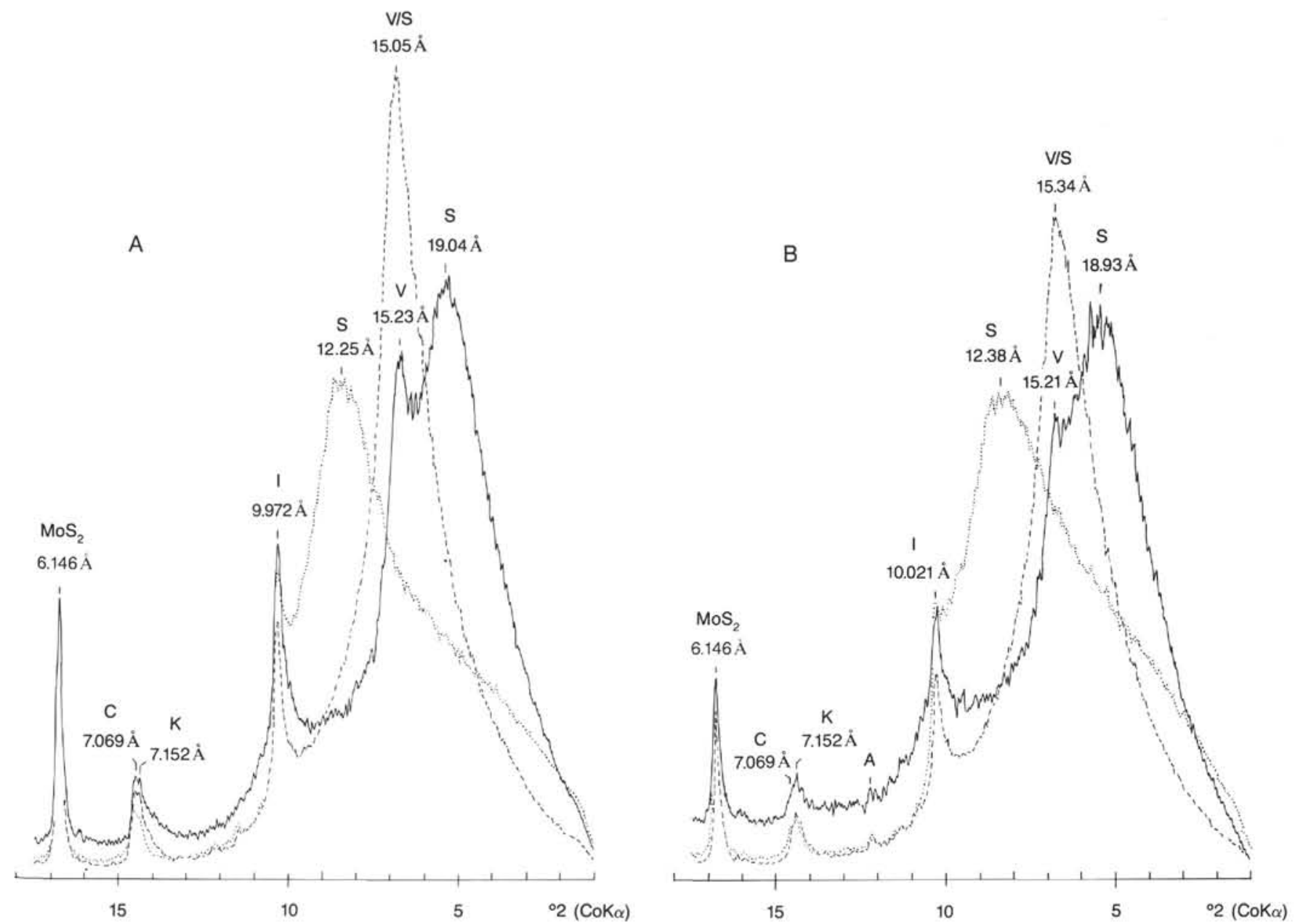

Figure 2. XRD patterns of the $<2-\mu \mathrm{m}$ fraction of the sediment samples measured at $100 \%$ (solid line), $50 \%$ (dashed line), and $0 \%$ relative humidity (dotted line). $\mathrm{S}=$ smectite, $\mathrm{V}=$ vermiculite, $\mathrm{C}=$ chlorite, $\mathrm{I}=$ illite, $\mathrm{A}=$ amphibole, $\mathrm{K}=$ kaolinite. The peak at $6.146 \AA$ is from the internal standard $\mathrm{MoS}_{2}$. A. Sample 114-699A-8H-2, 115-117 cm. B. Sample 114-699A-10H-1, 112-114 cm.

detrital grains, volcanic glass, and clay; Sample 114-699A$8 \mathrm{H}-2,108-110 \mathrm{~cm}$, is a diatom siliceous ooze with minor detrital grains and volcanic glass; Sample 114-699A-10H-1, 92-94 cm, consists of siliceous-diatom ooze; and Sample $114-699 \mathrm{~A}-18 \mathrm{H}-5,36-38 \mathrm{~cm}$, is a diatom-bearing nannofossil ooze. In Samples 114-699A-8H-2, 108-110 cm, and 114-699A$10 \mathrm{H}-1,92-94 \mathrm{~cm}$, "siliceous" refers to tiny particles of silica on the order of $<2 \mu \mathrm{m}$ in size. In the smear slide preparations they appear as tiny granular isotropic particles, and SEM observations show that they consist of small opaline microhemispheroids and aggregates as well as minute diatom fragments. The XRD analyses also showed that the majority of the $<2-\mu \mathrm{m}$ fraction was composed of opal.

\section{XRD Investigations}

\section{$<2-\mu m$ Fraction}

Sample 114-699A-8H-2, 115-117 cm, produced very little $<2-\mu \mathrm{m}$-size material on fractionation in comparison with Sample $114-699 \mathrm{~A}-10 \mathrm{H}-1,112-114 \mathrm{~cm}$. The XRD patterns for this fraction are shown in Figure 2. Minerals present include smectite, vermiculite, kaolinite, chlorite, illite, and amphibole.

Smectite was distinguished by a peak at $19.0 \AA$ at $100 \%$ relative humidity, which collapsed at $50 \%$ relative humidity to $15.05 \AA$ in Sample 114-699A-8H-2, 115-117 cm, and to 15.35 $\AA$ in Sample 114-699A-10H-1, 112-114 cm. At $0 \%$ relative humidity it shifted farther to 12.25 and $12.38 \AA$, respectively, for the two samples.

Vermiculite was distinguished by a peak at $15.18 \AA$ at $100 \%$ relative humidity, but at lower humidities the vermiculite peak coincides with the smectite peak and thus cannot be observed.

The relative peak intensity ratios of the clay minerals are shown in Table 3. For this calculation the peak height of the clay minerals was divided by the peak height of the internal standard of the same XRD trace. Smectite, exhibiting moderate crystallinity-measured at full (peak) width at half maximum (FWHM) - is by far the most dominant clay min-

Table 3. Peak intensity ratios in the $<2-\mu \mathrm{m}$ fraction and smectite crystallinity, Hole 699A.

\begin{tabular}{lcc}
\hline & $\begin{array}{l}8 \mathrm{H}-3, \\
52-54 \mathrm{~cm}\end{array}$ & $\begin{array}{l}10 \mathrm{H}-1, \\
112-114 \mathrm{~cm}\end{array}$ \\
\hline Smectite & 2.46 & 3.56 \\
Vermiculite & 0.80 & 0.82 \\
Illite & 0.72 & 0.87 \\
Kaolinite & 0.19 & 0.27 \\
Chlorite & 0.23 & 0.22 \\
aSmectite & 3.2 & 3.3 \\
\hline
\end{tabular}

${ }^{\mathrm{a}}$ Full (peak) width at half maximum in ${ }^{\circ} 2 \theta$. 


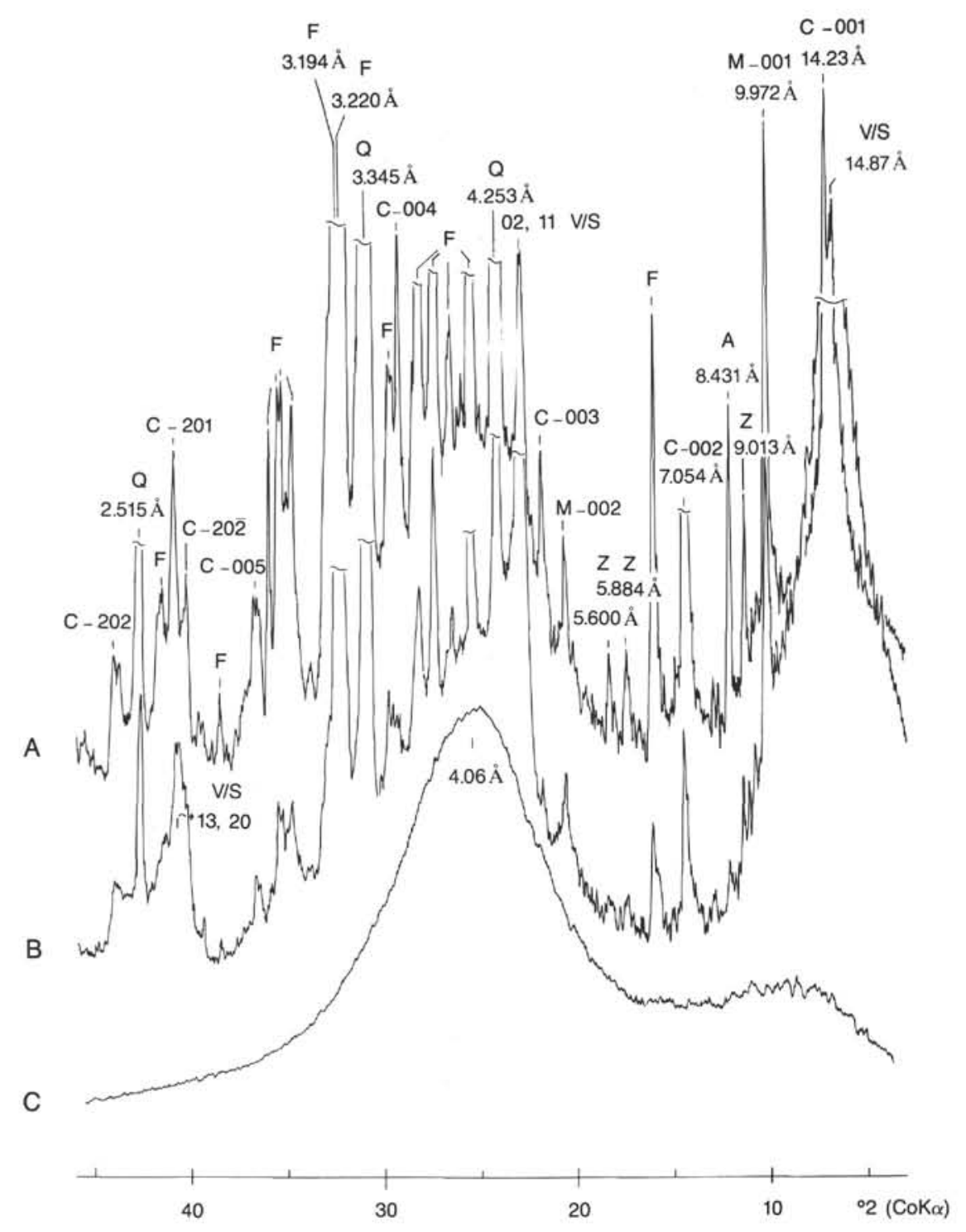

Figure 3. XRD patterns of the $>2-\mu \mathrm{m}$ fraction of Samples 114-699A-8H-2, 115-117 cm (A), and $114-699 \mathrm{~A}-10 \mathrm{H}-1,112-114 \mathrm{~cm}(\mathrm{~B})$, and an opal-A standard (C) measured at $50 \%$ relative humidity. $\mathrm{S}=$ smectite,$\quad \mathrm{V}=$ vermiculite,$\quad \mathrm{C}=$ chlorite,$\quad \mathrm{M}=$ mica,$\quad \mathrm{Z}=$ zeolite, $\mathrm{A}=$ amphibole, $\mathrm{F}=$ feldspar, $\mathrm{Q}=$ quartz.

eral in both samples. Relative peak intensities of smectite, vermiculite, illite, and kaolinite are slightly stronger in Sample 114-699A-10H-1, 112-114 cm, than in the overlying sample. Chlorite is the same in both cases. Peak intensity ratios for smectite, vermiculite, illite, kaolinite, and chlorite decrease in that order, except that chlorite and kaolinite in Sample 114-699A-8H-2, 115-117 cm, are reversed. The XRD patterns show traces of amphibole, additionally, in all samples.

\section{$>2-\mu m$ Fraction}

There are many crystalline components in the $>2-\mu \mathrm{m}$ fraction as well as a broad amorphous bulge centered at about $4.06 \AA$ (Fig. 3). Minor amounts of vermiculite/smectite, illite/ mica, and quartz occur in these samples, although there is slightly more vermiculite/smectite and illite/mica in Sample 114-699A-8H-2, 115-117 cm, than in Sample 114-699A-10H$1,92-94 \mathrm{~cm}$. In the latter sample there is also a minor amount of kaolinite. Amphiboles and zeolites are more important in Sample 114-699A-8H-2, 115-117 cm, than in Sample 114699A-10H-1, 112-114 cm.

The bulge in the XRD patterns at $4.06 \AA$ represents amorphous opal and is caused by the remains of siliceous microfossil frustules, such as diatoms, radiolarians, and sponge spicules, as well as possible neogenic phases. Figure 4 displays XRD traces for the $>2-\mu \mathrm{m}$ fraction from $13^{\circ}$ to $46^{\circ} 2 \theta$, excluding the peaks of the minerals previously mentioned to emphasize the opal bulge. As a comparison, the spectrum of fresh sponge spicules used as an internal standard is included (van Bennekom et al., in press). These diagrams clearly show that there are two additional small bulges at about 3.0 and 2.5 $\AA$ in both samples.

\section{Scanning Electron Microscope Investigations}

We classified a number of observed opaline diagenetic features in these sediments (summarized in Table 4) as follows: 


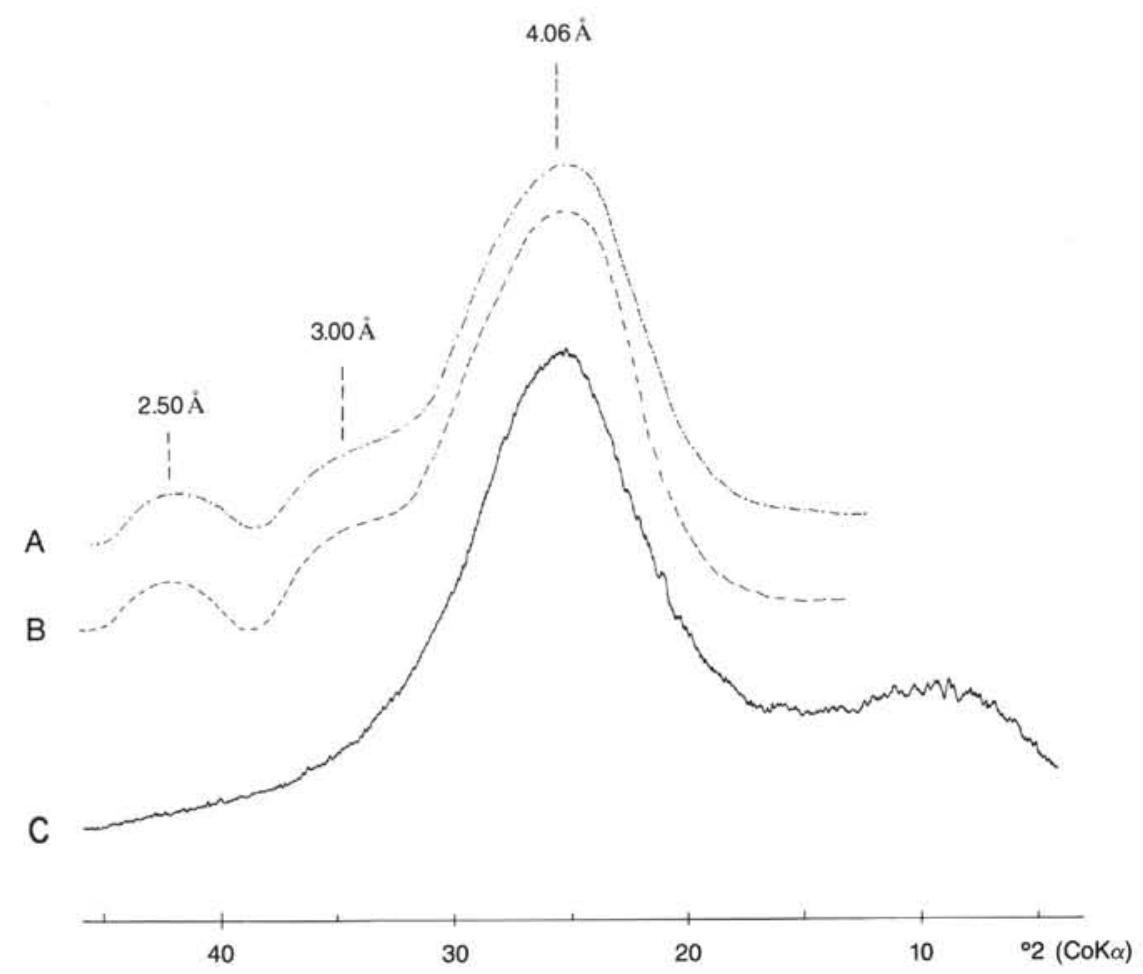

Figure 4. XRD patterns of the $>2-\mu \mathrm{m}$ fraction without the peaks of the crystalline components to emphasize the opal phases in Samples 114-699A-8H-2, 115-117 cm (A), and $114-699 \mathrm{~A}-10 \mathrm{H}-1,112-114 \mathrm{~cm}$ (B), and the opal standard (C). The bulge at $4.06 \AA$ represents opal-A. The other bulges probably represent the first onset of cristobalite crystallization: the bulge at $3.00 \AA$ probably represents an average of the (111) and (102) peaks of cristobalite, and that at $2.50 \AA$ the $(200)$ peak.

1. dissolution features, including biocorrosion of siliceous frustules (predominantly diatoms but also sponge spicules and radiolarians);

2. bacterial filaments that may be encrusted by opal, ranging from $<1 \mu \mathrm{m}$ to about $10 \mu \mathrm{m}$ in length and occurring in isolation or (rarely) in colonies;

3. neoformed opaline microhemispheroids ranging from 0.2 to $0.7 \mu \mathrm{m}$ in diameter;

4. a smooth-surfaced, structureless cement that embeds and drapes the filaments and microhemispheroids;

5 . various flaky structures that may be attached to the surface of siliceous frustules, occur in pore spaces, or form from coalesced microhemispheroids.

\section{Dissolution of Biosiliceous Frustules}

Our samples exhibit a range of dissolution intensities from (1) undissolved (PI. 1, Fig. 1); (2) slight dissolution that has removed some of the smooth outer layer of the frustule surface, resulting in a "bubbly" appearance (Pl. 1, Fig. 2); to (3) heavy dissolution that results in a porous surface as the ultrastructure of the frustule is uncovered (PI. 1, Figs. 3 and 4) (cf. Schmid and Schulz, 1979; Volcani, 1981; Li and Volcani, 1984). In Plate 1, Figure 3, it is possible to see that the highly porous ultrastructure consists of silica particles having dimensions of about $0.02-0.05 \mu \mathrm{m}$ (as judged from the SEM micrographs). These particles have circular cross sections that give them a spherical appearance. However, detailed observations of diatoms during growth by Schmid and Schulz (1979), Volcani (1981), and $\mathrm{Li}$ and Volcani (1984), as well as our own SEM observations of diatoms, indicate that the silica spheres are probably the heads of small, club-shaped silica columns.

In the deeper Samples 114-699A-10H-1, 92-94 cm, and $114-699 \mathrm{~A}-18 \mathrm{H}-5,36-38 \mathrm{~cm}$, we observed frustules showing various degrees of dissolution within the same sample. This is especially noticeable in Sample 114-699A-18H-5, 36-38 cm, where mechanically broken fragments with an apparently intact outer layer occur together with highly corroded frustules (Pl. 1, Figs. 1 and 4). This sample contains a diatom frustule exhibiting evidence of microbial bioerosion in the form of grooves of uniform width $(0.3-0.5 \mu \mathrm{m})$ between 1 and $2 \mu \mathrm{m}$ in length running either between areolae or around them (Pl. 1, Fig. 4, arrows).

It was not possible to make observations as to the state of frustule dissolution in Sample 114-699A-8H-2, 108-110 cm, because all of the particles are completely covered with neoformed siliceous blobs (PI. 5, Fig. 1). Edax analyses of corroded frustules generally show trace amounts of $\mathrm{Mg}, \mathrm{Al}$, $\mathrm{K}$, and $\mathrm{Fe}$ (and rarely $\mathrm{Ca}$ ) in their silica-dominated spectra (Fig. 5B).

\section{Filamentous Microbial Developments}

Microbial developments occur generally as isolated filaments and rarely in colonies. They were found essentially in Samples 114-699A-8H-2, 108-110 cm, and 114-699A-10H-1, 92-94 cm, although some rare, very small filaments were observed in Samples 114-699A-5H-5, 7-9 cm, and 114-699A$18 \mathrm{H}-5,36-38 \mathrm{~cm}$. 
Table 4. Sedimentologic characteristics and a summary of diagenetic structures, Hole 699A.

\begin{tabular}{|c|c|c|c|c|c|c|c|c|c|c|}
\hline \multirow{2}{*}{$\begin{array}{l}\text { Core, section, } \\
\text { interval (cm) }\end{array}$} & \multirow{2}{*}{$\begin{array}{l}\text { Depth } \\
\text { (mbsf) }\end{array}$} & \multirow[b]{2}{*}{ Age } & \multirow[b]{2}{*}{ Lithology } & \multirow{2}{*}{$\begin{array}{l}\text { Clay } \\
\text { content } \\
(\%)\end{array}$} & \multirow[b]{2}{*}{ Mn nodules } & \multirow{2}{*}{$\begin{array}{c}\text { Diatom } \\
\text { preservation }\end{array}$} & \multirow[b]{2}{*}{ Filaments } & \multirow[b]{2}{*}{ Microhemispheriods } & \multicolumn{2}{|c|}{ Flakes } \\
\hline & & & & & & & & & On diatom surface & In pore space \\
\hline \multicolumn{11}{|l|}{ 114-699A- } \\
\hline $5 \mathrm{H}-5,7-9$ & 43.17 & $\begin{array}{l}\text { early } \\
\text { Pliocene }\end{array}$ & $\begin{array}{l}\text { Detrital/ } \\
\text { volcanic glass/ } \\
\text { clay-bearing diatom ooze }\end{array}$ & 20 & - & $\begin{array}{l}\text { Generally } \\
\text { moderately } \\
\text { corroded; } \\
\text { replacement by } \\
\text { flakes rare }\end{array}$ & $\begin{array}{l}\text { Rare, tiny, } \\
\text { unencrusted filaments } \\
(<0.5 \mu \mathrm{m} \text { long })\end{array}$ & - & $\begin{array}{l}\text { Smooth-surfaced } \\
\text { flakes; tr } \mathrm{Al}, \mathrm{K} ; \mathrm{Fe}\end{array}$ & $\begin{array}{l}\text { Clays with } \\
\text { honeycombed } \\
\text { structure }\end{array}$ \\
\hline $\begin{array}{l}8 \mathrm{H}-2, \\
108-110\end{array}$ & 68.17 & $\begin{array}{l}\text { early or } \\
\text { middle } \\
\text { Miocene }\end{array}$ & $\begin{array}{l}\text { Detrital/volcanic } \\
\text { glass-bearing diatom } \\
\text { siliceous ooze }\end{array}$ & tr & Numerous & All encrusted & $\begin{array}{l}\text { Isolated filaments } \\
\text { common } \\
1.5-5 \mu \mathrm{m} \text { long. } \\
0.15-0.8 \mu \mathrm{m} \text { diameter; } \\
\text { slightly to very } \\
\text { encrusted; associated } \\
\text { with } \\
\text { microhemispheriods }\end{array}$ & $\begin{array}{l}\text { Cover whole sample; } \\
0.2-0.7 \mu \text { m diameter; } \\
\text { generally irregular } \\
\text { shape; simple to } \\
\text { complex aggregates; } \\
\mathrm{Si} / \mathrm{Al}=5.5-7 \text {, and tr } \\
\mathrm{Mg}, \mathrm{K}, \mathrm{Fe}\end{array}$ & $\begin{array}{l}\text { Sample tota } \\
\text { microhen }\end{array}$ & $\begin{array}{l}\text { ally covered by } \\
\text { mispheriods }\end{array}$ \\
\hline $10 \mathrm{H}-1,92-94$ & 85.52 & $\begin{array}{l}\text { latest } \\
\text { Oliogocene }\end{array}$ & Siliceous diatom ooze & $<10$ & - & $\begin{array}{l}\text { Highly corroded } \\
\text { to totally } \\
\text { encrusted; } \mathrm{SiO}_{2} \\
\text { and tr } \mathrm{Mg}, \mathrm{Al} \text {, } \\
\mathrm{K}, \mathrm{Fe}\end{array}$ & $\begin{array}{l}\text { Isolated filaments } \\
\text { common; rare } \\
\text { colonies; } 0.3-10 \mu \mathrm{m} \\
\text { long, } 0.1-0.6 \mu \mathrm{m} \\
\text { diameter; unencrusted } \\
\text { to heavily encrusted; } \\
\text { associated with } \\
\text { microhemispheriods } \\
\text { and flakes }\end{array}$ & $\begin{array}{l}\text { Localized coverage; } \\
0.3-0.5 \mu \mathrm{m} \text { diameter, } \\
\text { generally well } \\
\text { shaped; simple to } \\
\text { complex aggregates; } \\
\mathrm{Si} / \mathrm{Al}=5 \text {, and tr } \mathrm{Mg} \text {, } \\
\mathrm{K}, \mathrm{Fe}\end{array}$ & $\begin{array}{l}\text { Flakes with } \\
\text { microfissured } \\
\text { surfaces; } \\
\text { associated with } \\
\text { threads; } \mathrm{SiO}_{2} \text { and } \\
\text { tr } \mathrm{Al}, \mathrm{Mg}, \mathrm{K}, \mathrm{Fe}\end{array}$ & $\begin{array}{l}\text { 1. Microfissured } \\
\text { surface; rolled edges; } \\
\text { threads } \\
\text { 2. Flakes with } \\
\text { honeycombed } \\
\text { structure; } \mathrm{Si} / \mathrm{Al}=5 \text {, } \\
\text { and } \mathrm{tr} \mathrm{Mg}, \mathrm{K}, \mathrm{Fe}\end{array}$ \\
\hline $18 \mathrm{H}-5,36-38$ & 166.96 & $\begin{array}{l}\text { late } \\
\text { Oligocene }\end{array}$ & $\begin{array}{l}\text { Diatom-bearing } \\
\text { nannofossil ooze }\end{array}$ & $<10$ & - & $\begin{array}{l}\text { Uncorroded to } \\
\text { highly corroded; } \\
\mathrm{SiO}_{2} \text { and tr } \mathrm{Mg} \text {, } \\
\mathrm{Al}, \mathrm{K}, \mathrm{Fe}\end{array}$ & - & - & $\begin{array}{l}\text { Same as Sample } \\
114-699 \mathrm{~A}-10 \mathrm{H}-1 \text {, } \\
92-94 \mathrm{~cm}\end{array}$ & $\begin{array}{l}\text { Same as Sample } \\
114-699 \mathrm{~A}-10 \mathrm{H}-1 \text {, } \\
92-94 \mathrm{~cm} ; \mathrm{Si} / \mathrm{AI}= \\
2-6.5 \text {, and tr } \mathrm{Na}, \mathrm{Mg} \text {, } \\
\mathrm{K}, \mathrm{Ca}, \mathrm{Fe}\end{array}$ \\
\hline
\end{tabular}

\section{Microbial Colonies}

A good example of a microbial colony, observed in Sample $114-699 \mathrm{~A}-10 \mathrm{H}-1,92-94 \mathrm{~cm}$, is approximately 10 by $13 \mu \mathrm{m}$ in size and is composed of slender filaments that radiate from the center and edge of the colony (Fig. 6). The filaments are up to 3 $\mu \mathrm{m}$ in length and between 0.15 and $0.2 \mu \mathrm{m}$ in diameter. They are generally straight, but some are bent or even "hairpin" shaped. Their surfaces are generally smooth and appear nonsegmented. Most of the filaments look "fresh," although a few are encrusted toward their heads, apparently by silica (Fig. 6, arrow). The upper part of the colony, in contrast, is heavily encrusted and the closely packed tips of overgrown filaments form a mamillated surface. Adjacent to the colony, filaments are embedded in a groundmass composed essentially of microhemispheroids (see the following "Microhemispheroids" section). The heads of the filaments may protrude free and unencrusted out of the groundmass. In addition, small, stubby rods or segmented filaments about $3 \mu \mathrm{m}$ long and made of "cells" of about $0.3 \mu \mathrm{m}$ in size are found lying flat on the surrounding substrates. Small incipient colonies also occur in this area. Edax analyses of the surrounding sediment indicate a mainly silica composition with additional $\mathrm{Mg}, \mathrm{Al}, \mathrm{K}$, and $\mathrm{Fe}$ (Si/Al ratios 4.5-6.5).

\section{Isolated Microbial Filaments}

The microbial filaments observed exhibit a wide range of sizes and have been roughly grouped into three categories:

1. Filaments with a high length/width ratio that generally have a long, thin appearance. Lengths range from 1 to $10 \mu \mathrm{m}$ and diameters from 0.1 to $0.6 \mu \mathrm{m}$ (e.g., PI. 2, Figs. 1 and 3-5).

2. Short, stubby filaments with low length/width ratios. Lengths range from 0.3 to $2 \mu \mathrm{m}$ and diameters from 0.1 to 0.5 $\mu \mathrm{m}$ (e.g., Pl. 3, Figs. 3, 4, and 6).

3. Minute filaments that range from $0.05 \mu \mathrm{m}$ to a maximum of about $0.1 \mu \mathrm{m}$ in diameter and not more than a few microns in length (PI. 3, Fig. 2).
The long, thin filaments have various morphologies ranging from straight, bent, and wavy to hairpin-like shapes (Pl. 2). They may be erect and free-standing (Pl. 2, Figs. 1, 4 and 5) or their lower part may rest flat on the substrate (PI. 2, Fig. 6, and Pl. 3, Fig. 1). The filaments may be either smooth (Pl. 2, Figs. 1 and 2) or clearly segmented (PI. 2, Figs. 3-6). They are commonly irregular in thickness along their length due to variations in the thickness of the overgrowths. In many instances the overgrowths thicken toward the head of the filament, resulting in a club-shaped encrustation (Pl. 3, Fig. 5). In other cases, the bases of the filaments are encrusted by microhemispheroids (PI. 2, Fig. 4, and Pl. 7, Fig. 1). Small filaments may be associated with the bases of larger filaments (e.g., Pl. 3, Fig. 3, arrow). Plate 4 shows a variety of filament encrustations ranging from slight to moderate encrustation (Pl. 4, Figs. 1 and 3) to complex overgrowth (Pl. 4, Figs. 2 and 4). This relationship clearly demonstrates that the formation of overgrowth (whether microhemispheroids or "smooth cement"; Pl. 4, Figs. 3 and 4) postdates the growth of the microbial filaments.

The short, stubby filaments have many characteristics similar to the long, thin filaments. They may be oriented perpendicular to the substrate (Pl. 3, Figs. 3 and 4), lie on the substrate (PI. 3, Fig. 6), or even be embedded by it (Pl. 8, Figs. 3 and 4). In the latter example, they are so thickly intergrown that they give rise to rectangular patterns in the resulting groundmass. As with the larger filaments, they are commonly segmented (Pl. 3, Figs. 3 and 4) and may have coalesced microhemispheroids attached to their bases (Pl. 3, Fig. 3). Epiphytic microbes were observed on their surfaces in a few cases (Pl. 3, Fig. 6, arrows).

The third category of filaments is characterized by their extremely small size. These filaments average $0.05 \mu \mathrm{m}$ in diameter, but can be up to $0.1 \mu \mathrm{m}$ and in length up to $0.5 \mu \mathrm{m}$. Some exhibit a segmented morphology. The filaments may be associated with (1) microhemispheroids (Pl. 7, Fig. 2, "F"), which is more common in Sample 114-699A-10H-1, 92-94 cm, 


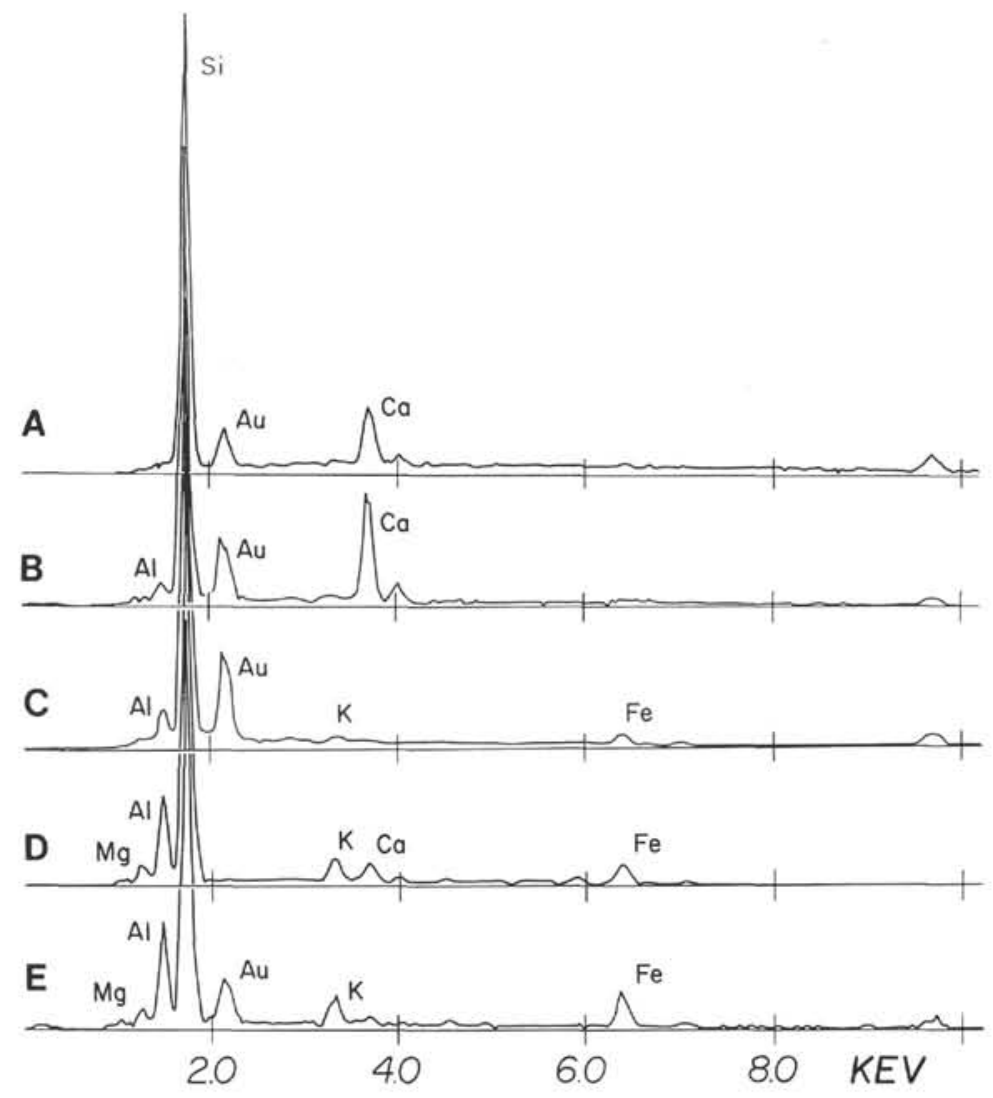

Figure 5. Edax/Tracor spectra. A. Smooth-surfaced diatom (PI. 1, Fig. 1) (Sample 114-699A-18H-5, 36-38 cm). B. Diatom with corroded surface (Sample 114-699A-18H-5, 36-38 cm). C. Neogenic smooth-surfaced flakes on diatom surface (PI. 9, Fig. 1) (Sample 114-699A-5H-5, 7-9 cm). D. Diatom completely overgrown by microhemispheroids (Sample 114-699A-10H-1, 92$94 \mathrm{~cm}$ ). E. Microbial colony (Fig. 6) (Sample 114-699A-10H-1, 92-94 cm). F. Sediment covered by microhemispheroids next to microbial colony (Fig. 6) (Sample 114-699A-10H-1, 92-94 cm). G. Microhemispheroid-covered groundmass (Sample 114-699A-10H-1, 92-94 cm). H. Neogenic flaky honeycombed minerals with smooth surfaces and fibrous edges, possibly smectite (Pl. 10, Fig. 2) (Sample 114-699A-10H-1, 92-94 cm). I. Neogenic flakes with microfissured surfaces and "rolled" edges (Sample 114-699A-18H-5, 36-38 cm).

than in Sample 114-699A-8H-2, 108-110 cm, or (2) flaky structures (described subsequently), in which case they appear to be closely linked with the neoformation of flakes. Filaments associated with flakes are found in all of the samples except Sample 114-699A-8H-2, 108-110 cm.

\section{Neoformed structures}

\section{Microhemispheroids}

We observed a number of opaline structures, characterized by perfect or roughly hemispheroidal morphologies and varying from 0.2 to $0.7 \mu \mathrm{m}$ in diameter (most commonly between 0.3 and $0.5 \mu \mathrm{m}$ in diameter), which we henceforth call "microhemispheroids." The study of stereopairs confirmed the absence of true spheres in these samples. The crowding of hemispherical bodies produces aggregates of subhemispherical forms exhibiting compromise boundaries ( $\mathrm{Pl}$. 6, Figs. 2-4). The stereopair study also revealed that some of the microhemispheroid-like structures are probably the tips of filaments embedded in the groundmass, or what we term a "smooth cement" (Pl. 3, Fig. 6, Pl. 5, Fig. 4, and PI. 7, Fig. 2). According to the X-ray-dispersive analyses, the microhemispheroids are composed predominantly of silica with trace amounts of $\mathrm{Al}, \mathrm{Mg}, \mathrm{K}$, and $\mathrm{Fe}$ (but rarely $\mathrm{Na}$ and $\mathrm{Ca}$ ) (Figs. $5 \mathrm{D}, 5 \mathrm{~F}$, and $5 \mathrm{G})$.

Microhemispheroids may occur as isolated structures, as on detrital grains (Pl. 5, Fig. 2, and Pl. 8, Fig. 1) or a sponge spicule (Pl. 6, Fig. 1). They commonly occur coalesced along the edges of particles (aforementioned examples) (e.g., the flat-surfaced particle at the bottom of Pl. 7, Fig. 2) and covering the groundmass (Pl. 5, Fig. 1, and PI. 7, Figs. 1 and 2).

In some cases, scattered microhemispheroids on the surfaces of diatom frustules may occlude some areolae (PI. 8, Fig. 2). Further overgrowth results in the whole skeleton being molded by microhemispheroids, which may invade the areolae (Pl. 2, Fig. 5). In more dramatic instances, frustules are completely overgrown by microhemispheroids and smooth cement (Pl. 5, Figs. 3 and 4).

Microhemispheroids coalesce to form a variety of aggregate structures. The simplest composite structure consists of two microhemispheroids with the appearance of having "budded"' (i.e., joined at one side) (arrows in PI. 4, Fig. 3, and Pl. 7, Fig. 2). In another instance, the alignment of microhemi- 


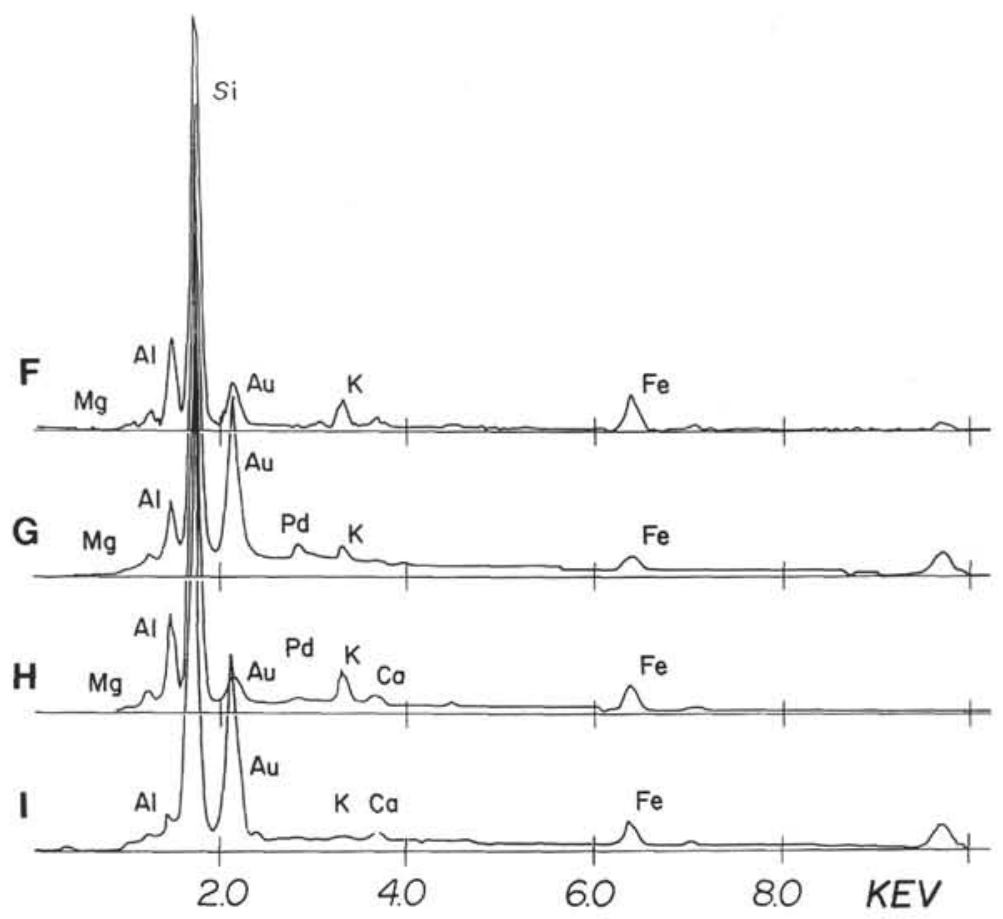

Figure 5 (continued).

spheroids having compromise boundaries may give rise to caterpillar-like structures, reminiscent of encrusted microbial filaments (PI. 5, Fig. 4, arrow). Microhemispheroids may also form planar, cubic-shaped aggregates (PI. 6, Fig. 4) or planar, circular conglomerations around a central microhemispheroid (Pl. 6, Fig. 2), with both types of aggregates showing compromise boundaries. Most commonly these microhemispheroids form more irregular masses that may overgrow filaments (PI. 3, Fig. 3, base of filament, and Pl. 4). The filaments decay and vanish, resulting in aggregates with a hollow center (PI. 6, Fig. 3, and Pl. 7, Fig. 1, arrow). Microhemispheroids may also encrust biogenic and nonbiogenic particles (Pl. 5, Figs. 1 and 3, Pl. 6, Fig. 1, Pl. 7, Fig. 2, and Pl. 8, Figs. 1 and 2). In one case, the encrusting microhemispheroids appear to have corroded the substrate to which they are attached (upper surface of spicule [arrows] in Pl. 6, Fig. 1). Finally, lateral coalescence of microhemispheroids can result in the formation of fat, tabular structures about $0.3 \mu \mathrm{m}$ thick with diameters of about $1 \mu \mathrm{m}$ (Pl. 4, Fig. 3, bottom right).

Microhemispheroids may, in turn, be partially embedded or completely draped by a smooth, structureless monolayer cement (Pl. 4, Fig. 3, and Pl. 7, Fig. 2, flat-surfaced particle). Plate 4, Figure 3, shows what appear to be moats around the bases of the embedded microhemispheres. The slightly hummocky surface of the cement suggests submerged or draped structures beneath. The interrelationships of all structures thus far described (i.e., filaments, microhemispheroids, and cement) appear to be complex: filaments are encrusted by microhemispheroids that become draped by a smooth cement upon which more filaments and/or microhemispheroids develop.

These neoformed structures were observed only in Miocene Sample 114-699A-8H-2, 108-110 cm, and uppermost Oligocene Sample 114-699A-10H-1, 92-94 cm, and not in the samples above nor below these. They cover and cement the whole of Sample 114-699A-8H-2, 108-110 cm, without exception (PI. 5, Fig. 1). Their distribution in Sample 114-699A$10 \mathrm{H}-1,92-94 \mathrm{~cm}$, is, however, patchy; parts of the sample are almost, but not totally, covered by neoformed structures (Pl. 8 , Fig. 1) whereas in other areas only isolated occurrences of microhemispheroids were found (Pl. 8, Fig. 2).

\section{Flaky Structures}

Using stereopairs of photographs we distinguished three types of flaky structures, all of which appear to be neoformed:

1. flakes associated with microhemispheroids;

2. flakes forming in the pore space;

3. flakes and diatom replacement.

\section{Flaky Accretions Associated with Microhemispheroids}

Flaky accretions are flat, tabular sheets with round, lobate edges. They are about $0.05 \mu \mathrm{m}$ thick and range from 0.5 to $1 \mu \mathrm{m}$ in size (Pl. 7, Fig. 1, aggregate, bottom left). These flakes are generally made of a smooth amorphous material, similar to what we subsequently describe as smooth cement. They grow horizontally by lateral coalescence of their lobes, which prograde as a thin sheet over the underlying flake. These flakes may pile on top of one another to form stacks, with some individual flakes protruding to form overhanging ledges. The stacked flakes are not always in contact with each other but may be separated by discontinuous, flat, horizontal cavities.

The surfaces of the flakes may be locally colonized by microhemispheroids ranging in size from 0.2 to $0.5 \mu \mathrm{m}$ or, less commonly, by short, rod-shaped stubby filaments up to 0.5 $\mu \mathrm{m}$ in length in angular orientation. Such nannoreliefs may become engulfed by the progradation of the next smooth, amorphous (structureless) layer, which, when thickening, may overgrow and drape the microhemispheroids to form a hummocky surface. Flattish microhemispheroids (blobs) give rise to flat flaky surfaces; thicker microhemispheroids produce a domed surface. Lateral deposition of the smooth cement may fill up the spaces between the lobes to build a continuous and nicely rounded margin around the flake.

The flakes and related stacks generally grow outward, or upward, from biogenic and detrital grains that they com- 


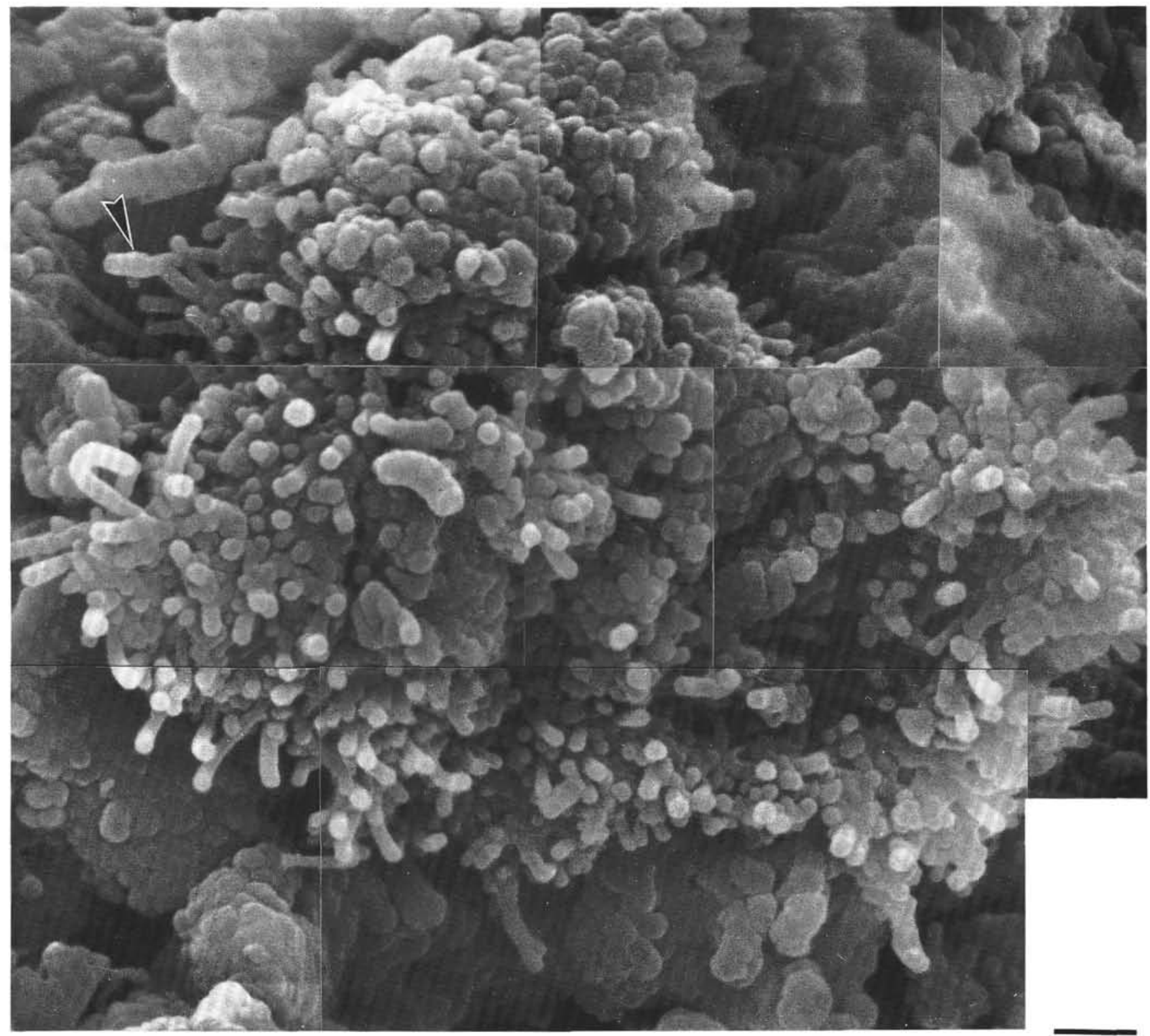

Figure 6. Bacterial colony consisting of generally unencrusted filaments (Sample 114-699A-10H-1, 92-94 cm). The upper part of the colony is formed of heavily encrusted filament heads. Isolated encrusted filament at arrow on left. See text for details. Scale $=1 \mu \mathrm{m}$.

pletely mask. In extreme situations microhemispheroids colonize the surface and the steep flanks of the stacks, yielding very complex "buildups" (Pl. 7, Fig. 1, aggregate, bottom left).

In some cases the flakes may reach several microns in size with edges showing rhombic or square indentations (PI. 8, Fig. 4) that seem to be guided by the arrangement of microhemispheroids, with a few guided by the growth patterns of short, stubby filaments. Flakes with more irregular serrated edges were also found (PI. 8, Fig. 3).

The distribution of these flaky accretions is essentially limited to the Miocene Sample 114-699A-8H-2, 108-110 cm, and the uppermost Oligocene Sample 114-699A-10H-1, 92$94 \mathrm{~cm}$. Edax/Tracor analyses of these structures give the same results as those for the microhemispheroids (i.e., a basically silica composition with trace amounts of $\mathrm{Mg}, \mathrm{Al}$, $\mathrm{K}$, and $\mathrm{Fe}$ ).

\section{Flakes Associated with Frustule Surfaces}

The flakes reported in this section differ from those described previously because of the absence of microhemispheroids and stacks.

The simplest type of flake is found associated with diatom frustule surfaces (Pl. 9, Fig. 1). This type was observed only in the youngest Sample 114-699A-5H-5, 7-9 cm. In this case, flakes with upward-curling edges appear to grow from the smooth surface of a frustule, partly occluding areolae. Interestingly, these flakes have the same smooth surface texture as the accreted flakes described previously.

A second type of flake overgrows diatoms as well as nannofossils. It has a subcircular to hexagonal outline and may reach about 1 to $2 \mu \mathrm{m}$ in size (Pl. 9, Fig. 3). The surface of such flakes is strongly textured and typically microfissured, as would be expected of a gel that has retracted ( $\mathrm{Pl}$. 
9, Fig. 2). In this instance the flake is edged with what appear to be small hemispheroids, $<0.05 \mu \mathrm{m}$, and curled-up flat or tubular extensions that may coalesce laterally (Pl. 9, Fig. 3). These types of flakes extend from the frustules into the pore space. In the pore space they may grade into minerals exhibiting a roughly flaky structure associated with filaments that also extend from other claylike minerals. Both flakes on the frustules and those in the pore space are interconnected by a three-dimensional network of fine threads (about 0.02 $\mu \mathrm{m}$ in diameter; Pl. 10, Fig. 1, arrows). These complex structures were found in all of the samples except Sample $114-699 \mathrm{~A}-8 \mathrm{H}-2,108-110 \mathrm{~cm}$.

$\mathrm{X}$-ray-dispersive analysis of the flakes gives very similar compositions to the spectra for flakes on frustules (i.e., very high $\mathrm{Si} / \mathrm{Al}$ ratios with trace amounts of $\mathrm{Mg}, \mathrm{K}$, and $\mathrm{Fe}$; Figs. $5 \mathrm{C}, 5 \mathrm{H}$, and $5 \mathrm{I})$.

\section{Replaced Diatom Frustule}

In the youngest, early Pliocene age, sample (114-699A$5 \mathrm{H}-5,7-9 \mathrm{~cm})$, we observed a diatom frustule partly altered and overgrown by flakes that also invade the areolae (Pl. 9, Fig. 4, replaced part indicated by an arrow). The frustule is highly corroded and exhibits a lacy microstructure. The outline of the areolae is now formed of curved, with some concentric, flakes whereas flat flakes, disposed at angles to each other, fill in the areolae. Lobate, concave, or curled-up flakes extend from the wall of the areolae to the outer surface of the frustule and are also formed on the altered outer surface.

\section{Smooth Cement or Coat}

Areas of neoformed siliceous coating with a smooth surface, which looks like a gel, occur between isolated microhemispheroids or groups of coalesced microhemispheroids in the groundmass (Pl. 3, Fig. 4, center right, and Pl. 4, Fig. 3). The smooth cement occurs on siliceous particles such as diatoms, sponge spicules, and detrital minerals and fills in the spaces between stacks of flakes, as described previously.

\section{DISCUSSION}

\section{Significance of the Microbes Preserved in the Studied Sediments}

The presence of microbial developments occurring as isolated filaments as well as in colonies raises three major questions as to (1) the timing of their growth, (2) their growth condition, (3) the relationship between preserved (and unpreserved) microbes and silica precipitation.

\section{Timing of Growth}

As reported in the description of microbes ("Filamentous Microbial Developments" section), we observed filaments in various stages of preservation, ranging from fresh-looking filaments and those with incipient encrustation (Fig. 6, Pl. 2, Fig. 1, and Pl. 4, Fig. 1) to heavily overgrown ones (Pl. 2, Fig. 4, and Pl. 4, Fig. 2). Although we are aware that delicate silicification of membranes and cell walls may contribute to the preservation of the fresh-looking colony, we have the impression that some filaments were living at the time of sampling, such as those forming part of the colony illustrated in Figure 6. This hypothesis is supported by microbiologist L. Margulis (pers. comm., 1987). We discard any possibility of contamination because the sampling was handled with care (all instruments were washed with alcohol before use) and the samples were fixed immediately after retrieval. Furthermore, filament growth predates as well as postdates the various phases of diagenetic silica deposition.

In fact, Miocene and latest Oligocene filaments dwelling in the uppermost sedimentary layers could not have been preserved for two reasons. First, the presence of manganese nodules in these sediments documents an oxidizing regime in which any dead organic filaments would have been at least partially, if not totally, oxidized before silicification. Second, the low clay content of these sediments suggests that they were winnowed, a situation that may be associated with the strong bottom currents that existed during the period of the latest Oligocene-middle Miocene hiatus (deduced from the measurement of physical properties above and below the hiatus). It is likely that this winnowing would have dismantled the shallow microbial growths and associated neogenic features (opaline microhemispheroids). In addition, we find it difficult to conceive that the association of fresh-looking filaments with filaments partly or totally overgrown by opaline microhemispheroids would span an interval of time ranging from the latest Miocene to the Holocene. However weak these arguments may be, we feel that the bulk of our findings points to a fairly recent, and possibly still active, development of microbial filaments and silica overgrowth.

Given the complex physical relationships between microhemispheroids that overgrow filaments to form aggregates on top of which new microbes may settle, it is most probable that some microhemispheroid aggregates are not strictly contemporaneous with the presently fresh-looking filaments, but were associated with older microbial coenoses; this is evidenced by the presence of silica aggregates surrounding hollow central cavities left over by decayed filaments.

We are aware that this proposed working hypothesis needs to be substantiated by SEM observation of etched samples and transmission electron microscope (TEM) observation with XRD of ultrathin sections, as well as by biogeochemical analysis.

At this point it is pertinent to address the question of the influence of burial depth and time on the development of the neoformed opaline structures that occur in the oldest, almost purely biosiliceous sediments. Although our observations show that the neoformation of opal took place in the past, we have no way of determining when this process actually started. Reports of opal-CT occurrences in diatomaceous Pliocene sediments at shallow burial depths from the Southwest Indian Ridge (Bohrmann et al., 1990), Maud Rise (Barker, Kennett et al., 1988), and Kerguelen Plateau (Weaver and Wise, 1973; Schlich, Wise, et al., 1989), however, show that great burial depths and long time periods are not necessary for the formation of opal-CT.

\section{Microbial Growth Conditions}

One of the most important limiting factors with respect to microbial growth is the organic carbon content of the sediments. Indeed, organic substrates usually have a dual nutritional role, serving as a source of organic carbon and as a source of energy at the same time (Stanier et al., 1976). Organic carbon contents measured in the vicinity of the lower or middle Miocene and uppermost Oligocene samples are extremely low $(0.04 \%$ for Sample $114-699$ A- 8 H- $2,108-110$ $\mathrm{cm}$, and $0.11 \%$ for Sample 114-699A-10H-1, 92-94 cm). The original values of organic carbon are difficult to estimate. They may possibly have been as high as $0.4 \%-0.5 \%$ in the surface sediments if we consider the position of the Polar Front, which was directly overhead at the time of deposition of the samples. On the other hand, the values may also have been lowered by oxidation processes and possibly by winnowing of the clay fraction and its adsorbed organic matter by strong 
bottom currents that would have been associated with the hiatus.

In fact, organic carbon values are low throughout the whole of the sediment column below 30 mbsf in Hole 699A. It is important for this discussion to determine whether microbes are still able to grow in sediments almost completely deprived of organic matter. It has long been known that microbes can dwell on very poor organic substrates. As an example, Kuznetsov et al. (1963, p. 42) reported that "a summary of the data in the literature on the influence of the contribution of organic substances on bacterial growth may be found in Rahn (1934) who states that a deficiency of nutritive substances begins to appear when the concentration falls below the level of $0.1-0.01 \%$. On the other hand, bacterial developments may take place even at considerably smaller concentrations of organic matter. ZoBell and Grant (1942) and ZoBell, Grant and Haas (1943) observed marine bacteria growing readily at concentrations of organic substances lower than $0.1 \mathrm{mg} / \mathrm{L}$." Accordingly, the low levels of organic carbon measured are not so low as to preclude any subrecent microbial development in the Miocene and uppermost Oligocene sediments at Hole $699 \mathrm{~A}$, although they will definitely restrict its intensity.

The pore-water chemistry indicates that the microbes we are reporting would dwell in dysaerobic conditions. Even if we do not know their metabolism, part of it could rely on nitrate reduction with either incorporation of nitrogen or the production of $\mathrm{NH}_{4}$. The latter could trigger small-scale fluctuations in $\mathrm{pH}$ that could possibly result in phases of silica dissolution and neoprecipitation.

Furthermore, if some of the larger filaments are cyanobacterial in nature, as suggested by their size and morphology, it appears most probable to one of us (C. M.) that the microbes described in this report represent only a part of the initial microbiota. Speaking from experience, this author suggests that the microecosystem should have also included a collection of small microbial organisms (bacteria and fungi) involved in various biogeochemical reactions and recycling nutrients (see, for instance, Pl. 3, Fig. 2, and Pl. 8, Fig. 3). These might not have been preserved or silicified. Also, many of the tiny microbes might well have been totally embedded in the silica precipitate, thus becoming indistinguishable. Such a situation has been observed in carbonates (C.L.V. Monty, unpubl. data; Monty and van Laer, 1984). This is presently being investigated by TEM.

\section{Microbes and Silica Precipitation}

As reported in the descriptions of the neogenic structures, silica can nucleate on microbial structures that may show incipient stages of silicification (Pl. 2, Fig. 1) or be completely embedded in complex clusters of microhemispheroids exhibiting compromise boundaries. We may thus surmise that microbes can act at least as a suitable substrate for silica nucleation and growth. Furthermore, in addition to considering the physical relationships, the possibility of biogeochemical reactions must also be taken into consideration. This applies not only to the variety of microbes we have illustrated but also, as noted previously, to those that might not have been preserved or recognized. Therefore, if polymerization of dissolved silica or dissolution of silica are apparently readily explained by physicochemical processes (for a synthesis, see Williams et al., 1985; Williams and Crerar, 1985), one cannot discard the possibility of microbial mediation.

According to Heinen and Oehler (1979), modern organisms interact with siliceous substances in three major ways: (1) "they contribute to the decomposition and solubilization of silicate material," (2) "they utilize silica in a dissimilatory fashion by incorporating it into their walls . . . in the dissolved form, keeping it there for a period of time in an unaltered or altered condition and then releasing it again as free silicic acid," and (3) "they also assimilate silica by taking it up in the dissolved form and polymerizing it within the cells, such that silica becomes an integral part of the organism itself and is not released prior to death."

Biological interactions with crystalline silicates would be ruled by the first process and would be irreversible (organisms would not participate in the formation of new silicates). Biological interaction with noncrystalline species of silica would be either reversible (as in the second dissimilatory process) or irreversible (as in the third assimilatory process).

In its simplest state, solubilization of polymeric, crystalline, or noncrystalline silica by organisms can proceed through the following process, among others (Heinen and Oehler, 1979). The reverse reaction applies to organisms that deposit silica.

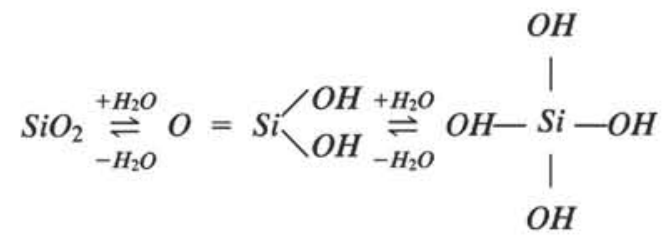

This type of reaction makes available soluble silica that may be taken up by the solubilizing organisms as well as by other organisms not necessarily involved in the solution process. Bacteria may also use this process to corrode the siliceous substrate and attach themselves (Oberlies and Pohlman, 1958; Meadows and Anderson, 1968; see also Pl. 1, Fig. 4). However, as pointed out by Heinen and Oehler (1979), mechanisms of silica polymerization in biological systems are usually more complex than the one shown and involve organosilicate intermediates. Heinen (1965), Voronkov et al. (1975), and Heinen and Oehler (1979) have proposed various reactions leading to the incorporation of silica into organic compounds; among the simplest ones are reactions involving carboxylic acids

$R-C_{\backslash \mathrm{OH}}+\mathrm{O}+\mathrm{Si}(\mathrm{OH})_{4} \rightarrow R-C_{\backslash \mathrm{O}} \mathrm{O}-\mathrm{Si}(\mathrm{OH})_{3}+\mathrm{H}_{2} \mathrm{O}$

or hydroxyl groups

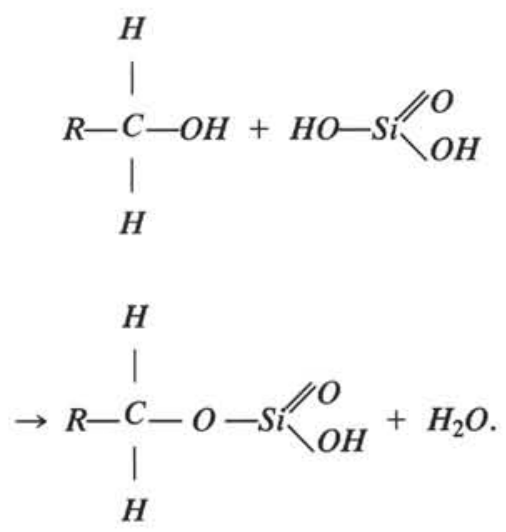

Compounds containing $\mathrm{C}-\mathrm{O}-\mathrm{Si}$ (as in the preceding) or C-N-Si and C-Si have been found in soils (e.g., Deuel et al., 1960; Hess et al., 1960) whereas C-O-Si and Si-H linkages 
have been found in the protein, nonprotein, and cell wall fractions of bacteria (Heinen, 1965). According to Heinen and Oehler (1979) the synthesis and breakdown of such organosilicon compounds is fundamental to assimilatory uptake and utilization of siliceous material by (micro)organisms as well as to some dissimilatory processes, such as process (2). Silica enrichments by cyanobacteria, bacteria, and fungi have been clearly documented by Glasovskaya (1950), Holzapfel and Engel (1954), and Heinen (1965, 1967), among others. According to Krumbein (1983), the reported enrichment can lead to the deposition of significant amounts of amorphous silica. This is in agreement with what we have observed and illustrated in Figure 6, Plate 4, Plate 6, Figure 3, and Plate 7, Figure 1. Although we do not have definite proof, to date, of microbial interference in silica diagenesis through their life processes, this seems to be highly probable; indeed, the microbes described and illustrated in situ in the diatomaceous sediments (together with those not preserved or distinguishable) are part of a microecosystem implying, therefore, interactions between life and silica or silicates.

Before closing this section we would like to extend the discussion by suggesting other possibilities of microbe-silica interaction drawn from diatom skeletogenesis.

Hecky et al. (1973) proposed a model in which the silicification of diatom frustules would be protein-mediated. Following this model, the proximal surface of the silicalemma of diatoms would consist of at least one mineralizing template rich in glycine and in hydroxyl-containing serine. Such a protein would contain one layer of hydroxyl groups on which molecules of silicic acid would condense. There is no reason why a similar type of polymerization could not be achieved by bacterial microfilms. The intervention of biofilms as sites of nucleation for silica would account for the precipitation of silica on detrital and biogenic particles, as well as on filaments, as illustrated in this study. In fact, the D-amino acids found in diatom oozes retrieved from east of the Scotia Arc by Warnke et al. (1979) have been interpreted as resulting from the degradation of microbial populations. This other possibility of microbial mediation is presently under study.

\section{Microhemispheroids}

Before discussing the significance and structure of microhemispheroids, a few words about the structure of precious opal may be of comparative interest. Opal forms "as a collection of closely packed spherical particles of amorphous silica, in other words, as an aggregate of giant colloidal sol particles"' (Darragh et al., 1976). These particles, ranging from 150 to $300 \mathrm{~nm}$ in size, are made up of two to six concentric shells of "primary particles, typically 20-50 nanometers in diameter"' (Darragh et al., 1976). In each layer the spheres are arrayed in hexagons. "When such layers are stacked on one another, the two simplest arrangements are "hexagonally close-packed' and 'face-centered cubic."' However, these authors concluded from diffraction patterns that "the layers of spheres in opal are most commonly stacked in random sequence" (i.e., a mixture of the two types of packing). In so-called potch opal the spheres are poorly ordered in shape and size. The requirements necessary for the development of perfectly shaped spheres include (1) "a geological formation in which steady state conditions can persist over long periods" and (2) that the deposition site necessarily be "free of mineral colloids such as clays, and of dissolved salts which could flocculate the primary particles into gel like masses or cause the growing spheres to stick together prematurely" (Darragh et al., 1976).

The second condition is not met in the type of situation found in the Hole $699 \mathrm{~A}$ sediments, not only because of the presence of clays and dissolved salts, but also because of the influence of life processes (i.e., microbes dwelling in the pore spaces) as well as the pattern of formation of these microhemispheroids. Most of the microhemispheroids we observed range from 0.2 to $0.7 \mu \mathrm{m}$ in size, with the majority between 0.3 and $0.5 \mu \mathrm{m}$, which is partly within the range of sphere size in precious opal. We do not see spheres as such in these samples. The most common structures are the microhemispheroids, which have a truncated base where they are attached to the substrate (Pl. 6, Fig. 1). These structures may, furthermore, cluster into aggregates where they exhibit compromise boundaries (Pl. 6 and Pl. 7, Fig. 2), which could be interpreted as resulting from space competition between two or more opaline bodies growing in a restricted area. There seems to be some sort of sporadic planar spatial organization of the aggregates, as illustrated in Plate 6, Figures 2 and 4, where microhemispheroids and the derived morphologies show a subconcentric disposition around the central sphere or a cubic arrangement. The difference with structures in opal lies in the fact that the arrangement we observed is not systematically three-dimensional.

The microhemispheroids considered here are generally larger than the spheres that form precious opal (130-300 nm, compared with the size of 200-700 nm in the Hole 699A samples). Spheres forming opal develop in a supersaturated liquid where they grow by successive addition of shells made of nannospheres (20-50 $\mathrm{nm})$. Once they reach a given size they settle through the liquid onto a substrate where they pile up in successive layers (Darragh et al., 1976). These spheres are accordingly "planktonic." The morphology of the Hole 699A microhemispheroids indicates that they grew attached to the substrate and are therefore "benthic." When microhemispheroids occur in isolation they have a perfectly hemispherical surface, similar to that of a gelatinous blob (e.g., PI. 6, Fig. 1, "H'). Seeding sites close to each other, however, result in crowding, thus leading to the widespread development of compromise boundaries and complex aggregates. It is difficult to understand how such aggregates could form according to the model of Darragh et al. (1976). If the elementary opal spheres forming in a supersaturated concentration were to settle onto a substrate instead of clustering around a nucleus, one would expect the buildup of conformable layers following the contours of the substrate. This process of formation could not, therefore, account for the formation of benthic microhemispheroids and derived morphologies. In the following, we propose two possible mechanisms of microhemispheroid growth:

1. A hemispherical seed nucleates on the substrate and strongly attracts nannospheres from the supersaturated pore water. The nannospheres would be conformably deposited around the seed in concentric layers. Having in mind the mechanisms described by Williams et al. (1985) and Williams and Crerar (1985), we do not favor this process of formation.

2. As noted previously, the microhemispheroids in the Hole 699A samples are not directly comparable to precious opal spheres and seem to have formed in a different manner. Although the method of formation remains undetermined as long as we do not have TEM observations, we propose that microhemispheroids may be cryptocrystalline accretions with a microspherulitic structure radiating out from a central point on the substrate. This could account for their morphology, the development of compromise boundaries, and the fact that microhemispheroids may overgrow each other to form aggregates. In this case, the phase of opal involved would be some sort of opal-CT. This hypothesis is supported by opal electron microscopist J. P. Gauthier (pers. comm., 1989) and possibly by evidence from the XRD spectra that indicates that a more crystalline component of opal is 
present in the Hole 699A samples. XRD spectra of the $>2-\mu \mathrm{m}$ fraction (including aggregates of microhemispheroids) of Samples 114-699A-8H-2, 115-117 cm, and 114$699 \mathrm{~A}-10 \mathrm{H}-1,112-114 \mathrm{~cm}$, indeed show two additional bulges at 3.0 and $2.5 \AA$ (Fig. 4). The bulge at $3.0 \AA$ probably represents the (111) and (102) peaks at 3.13 and $2.84 \AA$, respectively, of incipient cristobalite. The fact that we have only one averaged peak at $3.0 \AA$ instead of two distinct peaks is probably due to the broadness of the $3.0 \AA$ bulge, which, in turn, is also complicated by the peaks of the detrital minerals. The second bulge at $2.5 \AA$ probably represents the (200) peak of cristobalite. We are aware of the fact that there is also a smectite peak (13.20) at these angles. However, we conclude that, at least for Sample 114-699A-8H-2, 115-117 $\mathrm{cm}$, where there is very little smectite in the $>2-\mu \mathrm{m}$ fraction, the bulge at $3.0 \AA$ probably represents an average of the (111) and (102) cristobalite peaks. The fact that we find the same structures in the other sample strongly indicates that the bulge at $3.0 \AA$ in Sample $114-699 \mathrm{~A}-10 \mathrm{H}-1,112-114 \mathrm{~cm}$, is also cristobalite.

Nowhere did we observe the lepispheres or platelets that are supposedly typical of opal-CT. These neoformed microhemispheroids are of an order of magnitude smaller (0.2-0.7 $\mu \mathrm{m})$ than the $>2-\mu \mathrm{m}$ opal-CT spheres described in the literature (e.g., von Rad et al., 1977; Hein et al., 1978; Flörke et al., 1976) and, furthermore, are characterized by smooth surfaces. There is one reported instance of smooth-surfaced spheres of about 3- $\mu \mathrm{m}$ diameter that were identified as opal-CT on the basis of XRD analysis (Larue et al., 1987), but the authors do not discuss these results. In addition, Robert and Berthelin (1986, fig. 12-3c) illustrated silica spheres averaging $3 \mu \mathrm{m}$ in diameter growing at the surface of lichen thallus. The silica phase is not mentioned but the association with microorganisms is interesting.

At present, we tentatively identify the Hole 699A microhemispheroids as a transitional phase toward opal-CT solely on the grounds of lack of the typical opal-CT lepisphere morphology, the very small size range, and the XRD peaks at 3.0 and $2.5 \AA$. Those additional elements identified by Edax/ Tracor could have been adsorbed and/or represent chemical contamination by the substrate or surroundings.

At present, it is not clear whether the growth of microhemispheroids is triggered by a microbial seed as in ooids (Monty and van Laer, 1984) or by a microbial biofilm or whether it is not microbially mediated.

\section{Flaky Structures}

The formation of flaky accretions due to the cementation and draping of microhemispheroids by a smooth cement, prograding in successive sheets from the inner part of the flake to the outer part, poses a problem at the moment. We have no explanation for what triggers and directs their formation, although we have noted that their morphology could be controlled by the disposition of microhemispheroids and/or microbial rods. We also noted previously the similarity between the smooth coat and some amorphous-like precipitate that might have developed from a silica gel.

The XRD data from Samples 114-699A-8H-2, 115-117 cm, and $114-699 \mathrm{~A}-10 \mathrm{H}-1,112-114 \mathrm{~cm}$, indicate that the $<2-\mu \mathrm{m}$ fraction is dominated by smectite and that vermiculite, illite, chlorite, kaolinite, and amphibole are also present. There is very little $<2-\mu \mathrm{m}$ fraction in Sample 114-699A-8H-2, 115-117 $\mathrm{cm}$, and, indeed, we have observed no claylike structures at all in SEM Sample 114-699A-8H-2, 108-110 cm. As noted previously in the "Results" section, the whole sample is covered by neoformed microhemispheroids, which makes identification of any tiny clay flakes that might be present impossible. However, these overgrowths in Sample 114$699 \mathrm{~A}-10 \mathrm{H}-1,92-94 \mathrm{~cm}$, have an inhomogeneous distribution; where microhemispheroids are dominant, identification of tiny clay flakes is also impossible, but in other parts of this sample that are not overgrown by microhemispheroids, we observed a number of flaky structures believed to be neoformed, as described previously ("Results" section). It is the nature of these flakes as well as those in Samples 114-699A-5H-5, 7-9 $\mathrm{cm}$, and $114-699 \mathrm{~A}-18 \mathrm{H}-5,36-38 \mathrm{~cm}$, with which the following discussion is concerned.

A number of authors have documented the authigenic formation of smectite on diatom or other siliceous frustules (Chamley and Millot, 1972; Badaut et al., 1979; Badaut and Risacher, 1983; Cole and Shaw, 1983; Bohrmann, 1988). We also observed the formation of flakes on the surface of diatom frustules (PI. 9, Figs. 1 and 2), and their close relationship to the alteration of the frustules is clearly demonstrated in Plate 9, Figure 4. The Edax/Tracor spectra of the flakes indicate a predominance of silica and only trace amounts of $\mathrm{Al}$ (or, even more rarely, trace amounts of $\mathrm{Mg}, \mathrm{K}$, and $\mathrm{Fe}$ ). These analyses may reflect either the overwhelming silica background of the frustule or the fact that there really are only trace amounts of other cations adsorbed onto the flakes. We cannot, therefore, conclude that the flakes are smectite.

In fact, the only types of flakes in this sample that could possibly correspond to smectite on morphological grounds (Welton, 1984) are those with a honeycombed structure growing in the pore space (PI. 10, Fig. 2). The Edax/Tracor analyses of these flakes indicate a relatively high $\mathrm{Si} / \mathrm{Al}$ ratio of 5 (although a ratio of 2 was obtained from one analysis of Sample 114-699A-18H-5, 36-38 cm), which could perhaps be accounted for by contamination due to the presence of diatom debris mixed in among the clays.

The fact that we observed rod-shaped filaments guiding the growth of flaky accretions and (microbial?) threads extending from the border or rimming claylike flakes (Pl. 10, Fig. 1) in Samples 114-699A-10H-1, 92-94 cm, and 114-699A-18H-5, $36-38 \mathrm{~cm}$, suggests that microbial mediation may have played a role in flake formation. Further support for such mediation comes from the analysis of stereopairs of photographs of flakes forming in the pore space of Sample 114-699A-18H-5, $36-38 \mathrm{~cm}$, in which we observed an intergrowth of tiny filaments (hyphae?, $<0.05-\mu \mathrm{m}$ diameter) forming a complex three-dimensional framework in and on which is deposited a smooth, amorphous material. Thus, irregularly shaped flakes are formed in a juxtaposed, three-dimensional structure. If the filaments are microbial, that would imply that the formation of these flakes could be entirely controlled by microbes. However, additional documentation is necessary to confirm a microbial origin for the filaments and threads.

\section{Neoformed Structures in Other Leg 114 Holes}

It is appropriate to mention here the fact that structures similar to the microhemispheroids described previously were observed in a sample of lower Oligocene calcareous-clayey diatom ooze from Hole 701C. The microhemispheroids are associated with neoformed flakes as well as fine microbial filaments and threads. The development of these structures is not as widespread as in the lower or middle Miocene and uppermost Oligocene samples from Hole 699A but shows that this kind of neogenic formation is not limited to samples from just one drill hole.

\section{Physical Properties and Diagenesis}

What we have described and discussed in these pages is a diagenetic event or, at least, the initiation of a diagenetic event; it is interesting now to determine whether there is any 
characteristic signature that could identify it in the physical properties. In contrast to expectations, there is an increase in porosity and water content and a decrease in bulk density in these sediments below the hiatus at $68 \mathrm{mbsf}$. We believe that this is due to the fact that the finer, clay-sized material, which would fill in the pore spaces, has been winnowed away (it should be recalled that the XRD analyses indicate very little clay-sized material, especially in Sample 114-699A-8H-2, $115-117 \mathrm{~cm}$, which is closest to the hiatus). We conclude, therefore, that opal diagenesis and incipient cementation do not necessarily result in a decrease in porosity or water content.

\section{CONCLUSIONS}

The pilot study into possible microbial mediation in diagenesis presented here was based on the analyses of four samples of diatomaceous sediment, out of the more than 100 samples of mixed lithology taken. The samples were histologically preserved and stored in fixative immediately upon retrieval. These findings rely on about 500 SEM photographs, including stereopairs, which proved invaluable in studying diagenetic features.

Careful handling of subsamples allowed the description of in-situ microbial filaments, some of which are probably cyanobacteria, as well as in-situ microbial colonies. Observation at high magnification indicated that other microbial types (bacterial rods, cocci, and mycelium hyphae) could have been part of the original microecosystem. Furthermore, we have clearly illustrated various phases of encrustation of the microbial filaments by neogenic silica. Our observations lead us to conclude that microbial growths and, hence, their opaline overgrowths, could be fairly recent and may even be ongoing, although more sophisticated methods of investigation are needed to verify this. We do not know, at this stage, the exact role of their life processes on the overall diagenetic environment. Possible mechanisms of silica dissolution and precipitation by microorganisms as well as by the metabolites they release have been briefly discussed. Biogeochemical analyses are being launched to identify biochemical fossils (indicators of microbial activity).

Among the neogenic features we described is the development of opaline microhemispheroids that may overgrow all available substrates. On the basis of their growth pattern and the Edax/Tracor and XRD data, we suggested that they represent an incipient phase of cryptocrystalline, microspherulitic opal-CT. To date we have not found any definite evidence of possible microbial mediation in the formation of these microhemispheroids.

Other neogenic features described here include the formation of flaky accretions that may pile up to form stacks. Their growth processes seem to be complex and involve two phases: (1) microhemispheroids, the arrangement of which may guide the growth of the flakes, and (2) the formation of a smooth cement of undetermined nature, which engulfs and drapes the microhemispheroids. In other cases, we observed the very close interrelationship between the growth pattern of small, stubby filaments and the morphology (square indentations) and buildup of flakes (Pl. 8, Fig. 4).

Finally, we described the formation of various flakes growing on diatom frustules as well as in pore space. They include what appear to be pure structureless silica phases with retraction features as well as neomorphic clays, some of which we tentatively identified as smectite. Other claylike phases observed in stereopairs appear to grow by the filling-in of a three-dimensional framework of tiny branching filaments with a smooth, amorphous material.
Since the Edax/Tracor and XRD analyses were not sufficient to satisfactorily identify all of the neogenic phases observed, this study will be completed by TEM associated with XRD.

In conclusion, as far as we can judge from the available sediment samples and in consideration that what follows must necessarily be a temporary statement until we have studied more samples, the neogenic features we have reported here (microhemispheroids and flakes) appear as a biodiagenetic event that seems to start below 43.14 mbsf and culminate between 68.7 and $85.5 \mathrm{mbsf}$, dying out below. It does not seem to be bound to specific trends or peaks in the pore-water chemistry (dissolved $\mathrm{SiO}_{2}$, alkalinity, $\mathrm{pH}$, and carbonate content).

At the time of submission, many of the neogenic features reported here are described for the first time and clearly show that the diagenesis of biosiliceous ooze is more complicated than the simple diagenetic pathway of amorphous opal-A $\rightarrow$ opal-CT lepispheres, which were not found in our study. Furthermore, the reported observations, although limited, point toward microbial mediation in silica and possibly clay diagenesis, which might involve processes more complex than those reported in the recent literature and models on plain physicochemical grounds.

\section{ACKNOWLEDGMENTS}

C. M. acknowledges Total and the Fonds National de la Recherche Scientifique for funding as well as the Ministry of Employment (Belgium) for making technical assistance available. F. W. thanks the Ocean Drilling Program for being able to take part in Leg 114 and for extra samples and the Deutsche Forschungsgemeinschaft for financial support. We greatly appreciate the help given by Sabine Peter in the laboratory. Alain Barreau provided invaluable expertise with the SEM and Aad Vaars with the XRD. Alain Cossard is thanked for help with the plate and diagram production.

\section{REFERENCES}

Badaut, D., and Risacher, F., 1983. Authigenic smectite on diatom frustules in Bolivian saline lakes. Geochim. Cosmochim. Acta, 47:363-375.

Badaut, D., Risacher, F., Paquet, H., Eberhart, J.-P., and Weber, F., 1979. Néoformation des minéraux argileux à partir de frustules de diatomées: le cas des lacs de l'Altiplano bolivien. C. R. Acad. Sci. Paris, 289D:1191-1193.

Barker, P. F., Kennett, J. P., et al., 1988. Proc. ODP, Init. Repts., 113: College Station, TX (Ocean Drilling Program).

Bohrmann, G., 1988. Zur sedimentationsgeschichte von biogenem opal im nördlichen Nordatlantik und dem Europäischen Nordmeer (DSDP/ODP-Bohrungen 408, 642, 643, 644, 646 und 847). Ber. Sonderforschungsbereich 313, Univ. Kiel, 9:1-221.

Bohrmann, G., Kuhn, G., Abelmann, A., Gersonde, R., and Fütterer, D., 1990. A young porcellanite occurrence from the Southwest Indian Ridge. Mar. Geol., 92:155-163.

Calvert, S. E., 1974. Deposition and diagenesis of silica in marine sediments. Spec. Publ. Int. Assoc. Sedimentol., 1:273-299.

Chamley, H., and Millot, G., 1972. Néoformation de montmorillonite à partir de diatomées et de cendres dans les sédiments marins de Santorin (Méditerranée orientale). C. R. Acad. Sci. Paris, 274D:1132-1134.

Ciesielski, P. F., Kristoffersen, Y., et al., 1988. Proc. ODP, Init. Repts., 114: College Station, TX (Ocean Drilling Program).

Cole, T. G., and Shaw, H. F., 1983. The nature and origin of authigenic smectites in some recent marine sediments. Clay Miner., 18:239-252.

Darragh, P. J., Gaskin, A. J., and Sanders, J. V., 1976. Opals. Sci. Am., 234:84-94. 
Dean, W. E., Leinen, M., and Stow, D.A.V., 1984. Classification of deep-sea, fine grained sediments. J. Sediment. Petrol., 55:250256.

Deuel, H., Dubach, P., Mehta, N. C., and Bach, R., 1960. Zur chemie der organischen substanz des bodens. Schweiz. Z. Hydrol., 22:111-121.

Flörke, O. W., Hollmann, R., von Rad, U., and Rösch, H., 1976. Intergrowth and twinning of opal-CT lepispheres. Contrib. Mineral. Petrol., 58:235-243.

Flörke, O. W., Jones, J. B., and Segnit, E. R., 1975. Opal-CT crystals. Neues Jahrb. Mineral. Monatsh., 8:369-377.

Froelich, F., 1974. Nature, importance relative et place dans la diagenèse des phases de silice présentes dans les silicifications de craies du Bassin océanique de Madagascar (Océan Indien) et du Bassin de Paris. Bull. Soc. Geol. Fr., 16:498-508.

Glasovskaya, M. A., 1950. Rock weathering in the arable belt of Central Tyan-Shan. Tr. Pochv. Inst., Akad. Nauk SSSR, 34:28-48.

Hecky, R. E., Mopper, K., Kilham, P., and Degens, E. T., 1973. The amino acid and sugar composition of diatom cell walls. Mar. Biol., 19:323-331.

Hein, J. R., Scholl, D. W., Barron, J. A., Jones, M. G., and Miller, J., 1978. Diagenesis of late Cenozoic diatomaceous deposits and formation of the bottom simulating reflector in the southern Bering Sea. Sedimentology, 25:155-181.

Heinen, W., 1965. Siliciumstoffwechsel bei mikroorganismen. Arch. Mikrobiol., 52:49-68.

1967. Ion-accumulation in bacterial system. III. Respiration-dependent accumulation of silicate by a particulate fraction from Proteus mirabilis cell-free abstracts. Arch. Biochem. Biophys., 120:101-107.

Heinen, W., and Oehler, J. H., 1979. Evolutionary aspects of the biological involvement in the cycling of silica. In Trudinger, P. A., and Swaine, D. J. (Eds.), Biogeochemical Cycling of Mineral Forming Elements: Amsterdam (Elsevier), 431-443.

Hess, R., Bach, R., and Deuel, H., 1980. Modelle für reaktionen zwischen organischen und mineralischen substanzen im boden. Experimentia, 16:38-45.

Holzapfel, L., and Engel, W., 1954. Der einfluss organischer kieselsäureverbindungen auf das wachstum von Aspergillus niger and Triticum. Z. Naturforsch., 93:602-606.

Kastner, M., 1981. Authigenic silicates in deep sea sediments: formation and diagenesis. In Emiliani, C. (Ed.), The Sea (vol. 7): New York (Wiley), 915-980.

Kastner, M., and Gieskes, J. M., 1983. Opal-A to opal-CT transformation: a kinetic study. In Iijima, A., Hein, J. R., and Siever, R. (Eds.), Siliceous Deposits in the Pacific Region: Amsterdam (Elsevier), 211-227.

Kastner, M., Keene, J. B., and Gieskes, J. M., 1977. Diagenesis of siliceous oozes I. Chemical controls on the rate of opal-A to opal-CT transformation-an experimental study. Geochim. Cosmochim. Acta, 41:1041-1059.

Krumbein, W. E., 1983. Microbial Geochemistry: Oxford (Blackwell Sci.).

Kuznetsov, S. I., Ivanov, M. V., and Lyalikova, N. N., 1963. Introduction to Geological Microbiology: New York (McGrawHill).

Larue, D. K., Gortner, C. W., and Torrini, R., Jr., 1987. Silica diagenesis in accreted Eocene siliceous rocks (horizon $\mathrm{A}^{\mathrm{c}}$ ) on Barbados. J. Sediment. Petrol., 57:1033-1039.

Li, C.-W., and Volcani, B. E., 1984. Aspects of silicification in wall morphogenesis of diatoms. Philos. Trans. R. Soc. London, B304:519-528.

Meadows, P. S., and Anderson, J. G., 1968. Microorganisms attached to marine sand grains. J. Mar. Biol. Assoc. U.K., 48:161-175.

Monty, C.L.V., and van Laer, P., 1984. Experimental radial calcite ooids of microbial origin and fossil counterparts. IAS 5th Eur. Reg. Meet., Abstracts, 446-447.
Oberlies, F., and Pohlmann, G., 1958. Einwirkung von mikroorganismen auf glas. Naturwissenschaften, 45:487.

Rahn, O., 1934. Salt, a study of its bacterial content. Nat. Provis.

Riech, V., and von Rad, U., 1979. Silica diagenesis in the Atlantic Ocean: diagenetic potential and transformations. In Talwani, M., Hay, W., and Ryan, W.B.F. (Eds.), Deep Drilling Results in the Atlantic Ocean: Continental Margins and Paleoenvironment: Washington (Am. Geophys. Union), 315-340.

Robert, M., and Berthelin, J., 1986. Role of biological and biochemical factors in soil mineral weathering. In Huang, P. M., and Schnitzer, M. (Eds.), Interactions of Soil Minerals with Natural Organics and Microbes. SSSA Spec. Publ., 17:453-495.

Schlich, R., Wise, S. W., et al., in press. Proc. ODP, Init Repts., 120: College Station, TX (Ocean Drilling Program).

Schmid, A.-M., and Schulz, D., 1979. Wall morphogenesis in diatoms: deposition of silica by cytoplasmic vesicles. Protoplasma, 100:267-288.

Stanier, R. Y., Adelberg, E. A., and Ingraham, J., 1976. The Microbial World: New Jersey (Prentice Hall).

van Bennekom, A. J., Jansen, J.H.F., van der Gaast, S. J., van Iperen, Y. M., and Pieters, J., in press. Aluminium-rich opal: an intermediate in the preservation of biogenic silica in the Zaire (Congo) deep-sea fan. Deep-Sea Res., Part A.

van der Gaast, S. J., Mizota, C., and Jansen, J.H.F., 1986. Curved smectite in soils from volcanic ash in Kenya and Tanzania: a low-angle X-ray powder diffraction study. Clays Clay Miner., 34:665-671.

van der Gaast, S. J., and Vaars, A. J., 1981. A method to eliminate the background in X-ray diffraction patterns of oriented clay mineral samples. Clay Miner., 16:383-393.

Volcani, B. E., 1981. Cell wall formation in diatoms: morphogenesis and biochemistry. In Simpson, T. L., and Volcani, B. E. (Eds.), Silicon and Siliceous Structures in Biological Systems: Berlin (Springer-Verlag), 157-200.

von Rad, U., Riech, V., and Rösch, H., 1977. Silica diagenesis in continental margin sediments off northwest Africa. In Lancelot, Y., and Seibold, E., et al., Init. Repts. DSDP, 41: Washington (U.S. Govt. Printing Office), 879-897.

Voronkov, M. G., Zelchan, G. I., and Lukevitz, E., 1975. Silizium und Leben: Berlin (Akademie-Verlag).

Warnke, D. A., Blunt, D. J., and Pollock, G. E., 1979. Amino acid stereochemistry in siliceous oozes: indications of bacterial activity. Antarct. J. U.S., 14:134-136.

Weaver, F. M., and Wise, S. W., 1973. Early diagenesis of bedded chert. Antarct. J. U.S., 8:298-330.

Welton, J. E., 1984. SEM Petrology Atlas. Methods Expl. Ser., AAPG.

Williams, L. A., and Crerar, D. A., 1985. Silica diagenesis, II. General mechanisms. J. Sediment. Petrol., 55:313-321.

Williams, L. A., Parks, G. A., and Crerar, D. A., 1985. Silica diagenesis, I. Solubility controls. J. Sediment. Petrol., 55:301311.

Wise, S. W., Jr., and Hsü, K. J. 1971. Genesis and lithification of a deep sea chalk. Eclogae Geol. Helv., 64:273-278.

ZoBell, C. E., and Grant, C. W., 1942. Bacterial activity in dilute nutrient solutions. Science, 96:189.

ZoBell, C. E., Grant, C. W., and Haas, H. F., 1943. Marine microorganisms which oxydize petroleum hydrocarbons. $A A P G$ Bull., 27:1175.

Date of initial receipt: 2 May 1989

Date of acceptance: 9 January 1990

Ms 114B-121 


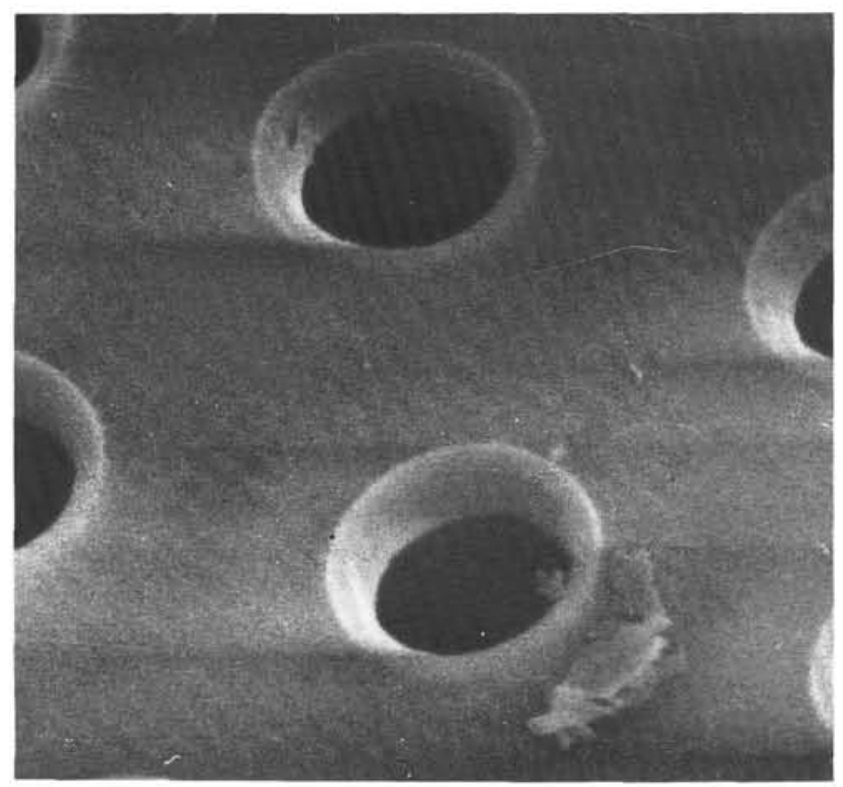

1

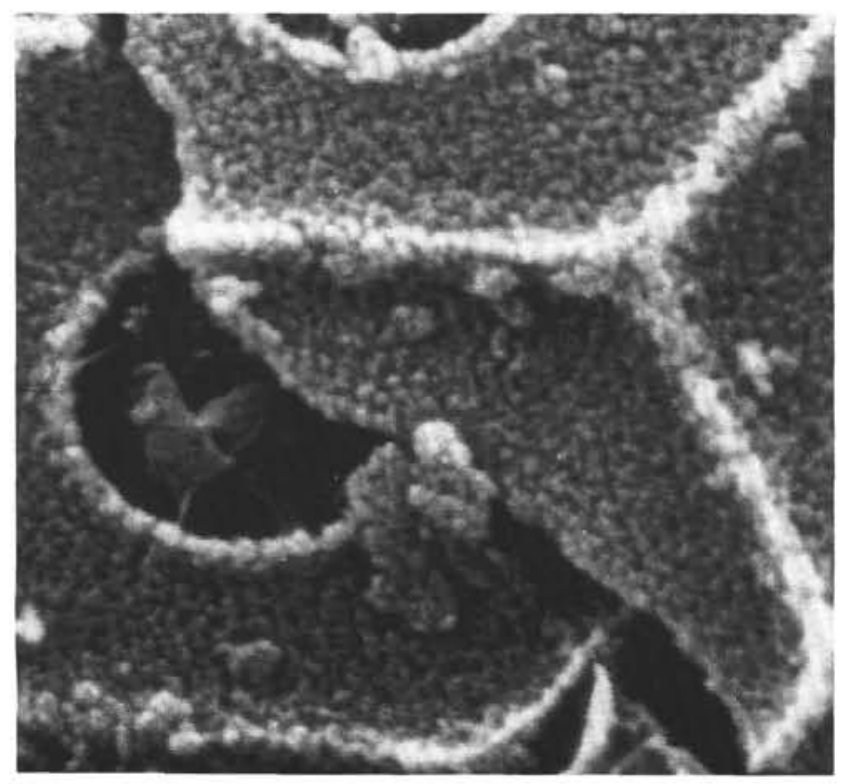

3

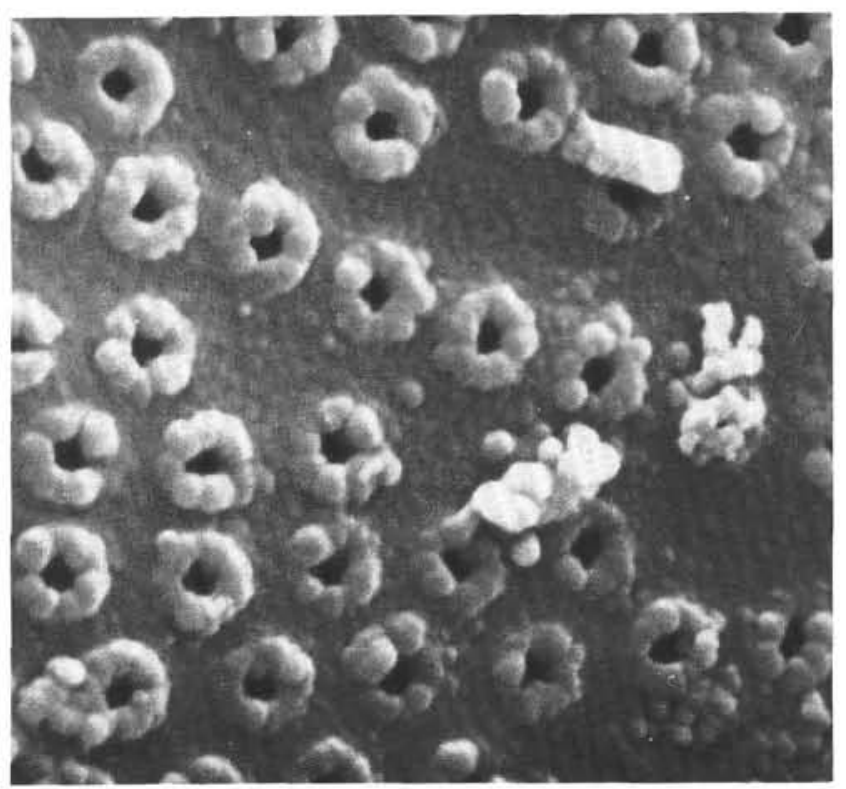

2

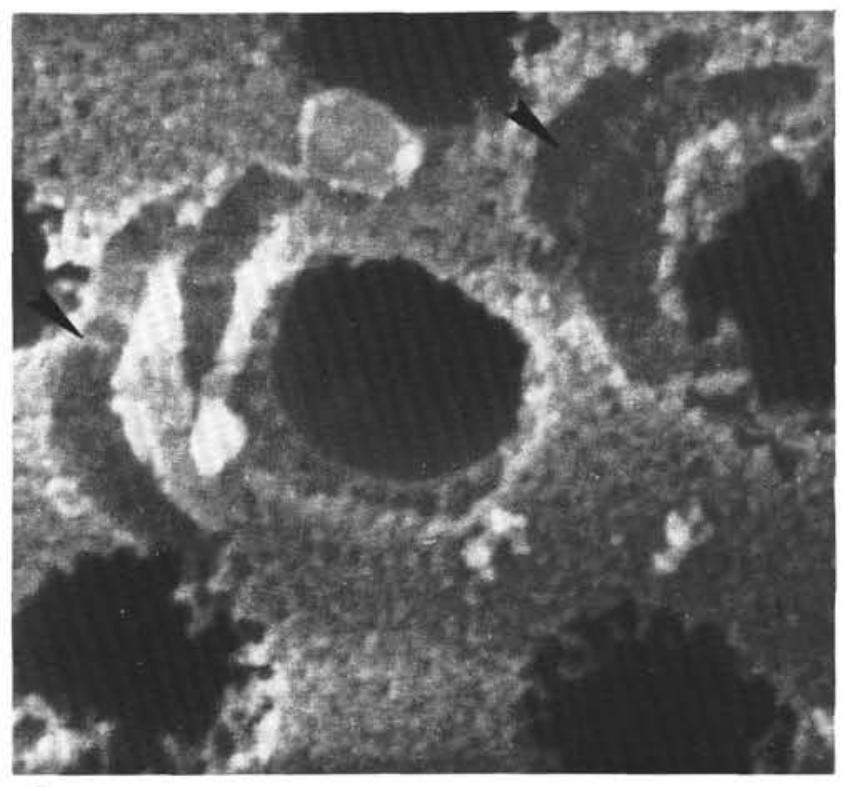

4

Plate 1. Dissolution of diatom frustules. Scale $=1 \mu \mathrm{m}$. 1. No dissolution, smooth surface (Sample 114-699A-18H-5, 36-38 cm). 2. Slight dissolution, with removal of the outer layer to uncover the "hummocky" ultrastructure (Sample 114-699A-10H-1, 92-94 cm). 3. Strong dissolution resulting in a highly porous surface (Sample 114-699A-10H-1, 92-94 cm). 4. Curved grooves (arrows) due to bacterial bioerosion of corroded diatom frustules (Sample 114-699A-18H-5, 36-38 cm). 


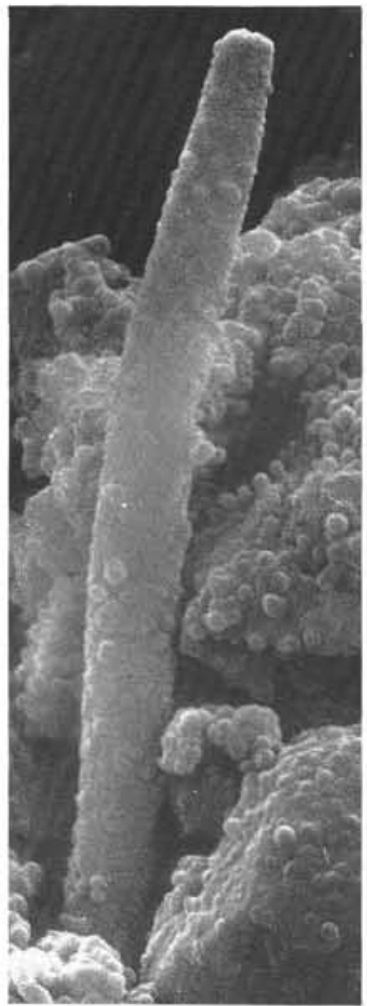

1

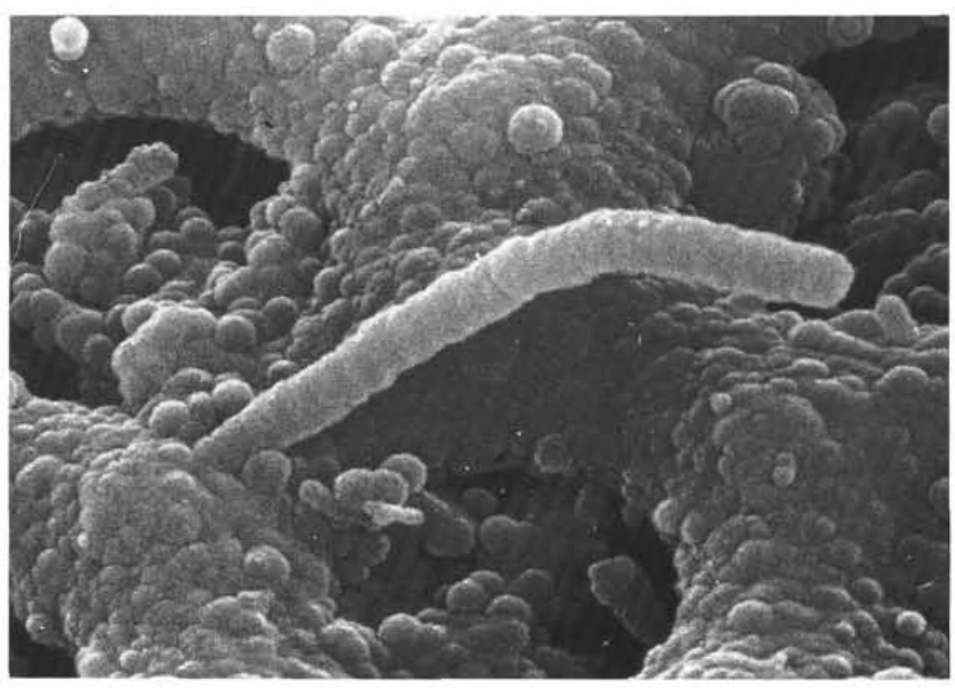

5
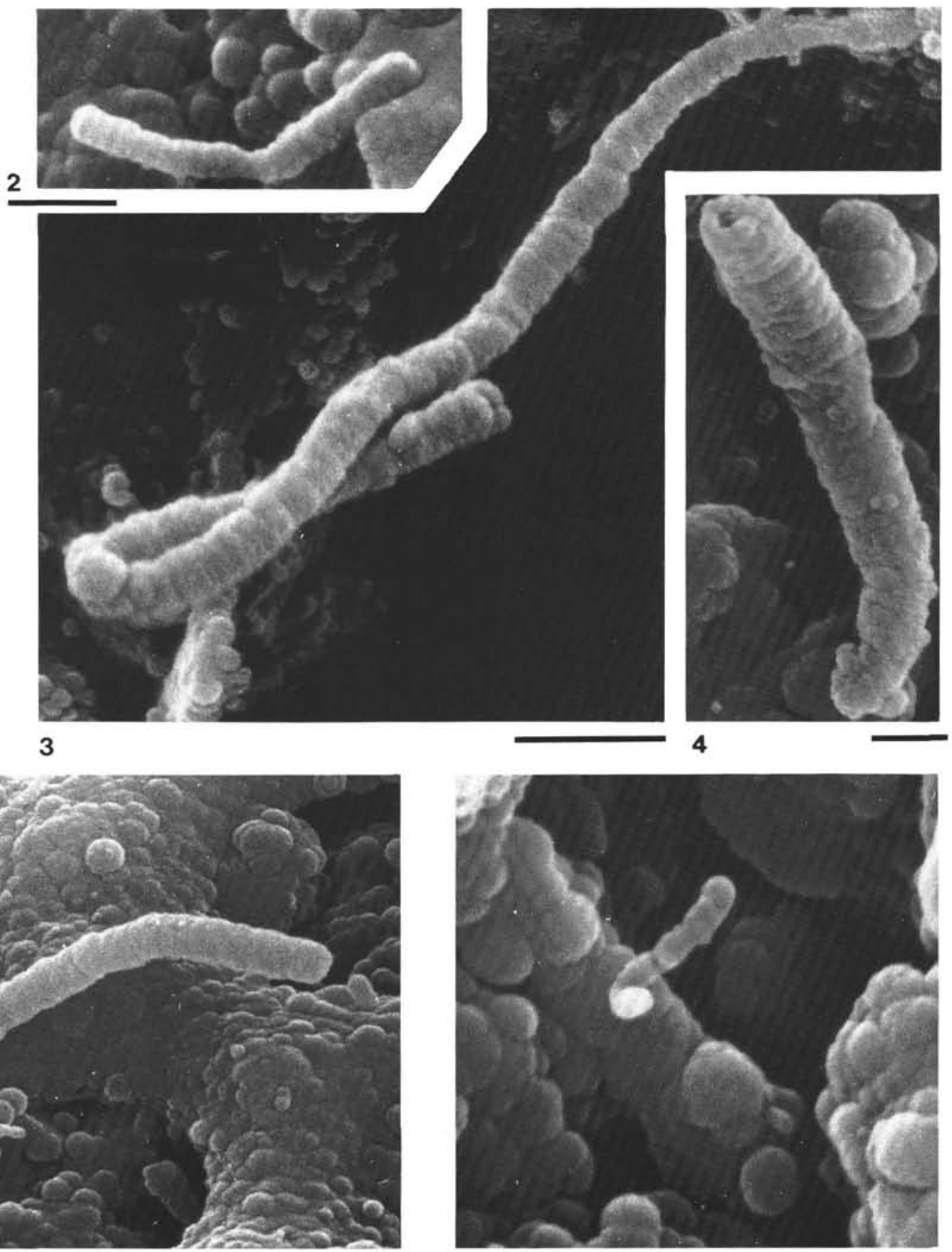

6

Plate 2. Filamentous bacteria. 1. Long, thin filament exhibiting incipient overgrowth by microhemispheroids (Sample 114-699A-10H-1, 92-94 cm). Scale $=1 \mu \mathrm{m}$. 2. Small, thin filament, partly embedded to the right in a smooth cement (Sample 114-699A-10H-1, 92-94 cm). Scale $=0.5 \mu \mathrm{m}$. 3. Long, thin filament with a hairpin shape showing slight encrustation (Sample 114-699A-10H-1, $92-94 \mathrm{~cm})$. Scale $=1 \mu \mathrm{m}$. 4. Long, thin siliceous filament with hollow center indicating possible escape or decay of the original "trichome" (Sample 114-699A-10H-1, $92-94 \mathrm{~cm}$ ). Scale $=0.5 \mu \mathrm{m}$. 5. Filament firmly anchored in a diatom frustule that is completely overgrown by microhemispheroids (Sample 114-699A-10H-1, 92-94 cm). Scale $=1 \mu \mathrm{m}$. 6. Segmented bacterium attached to the completely encrusted surface of a larger microbial filament (Sample 114-699A-8H-2, 108-110 cm). Scale $=1 \mu \mathrm{m}$. 


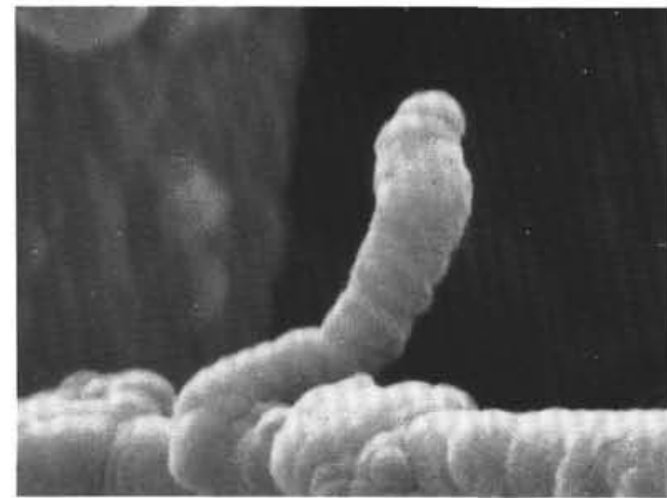

1

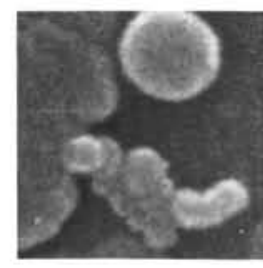

2

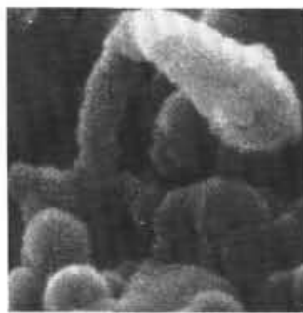

5

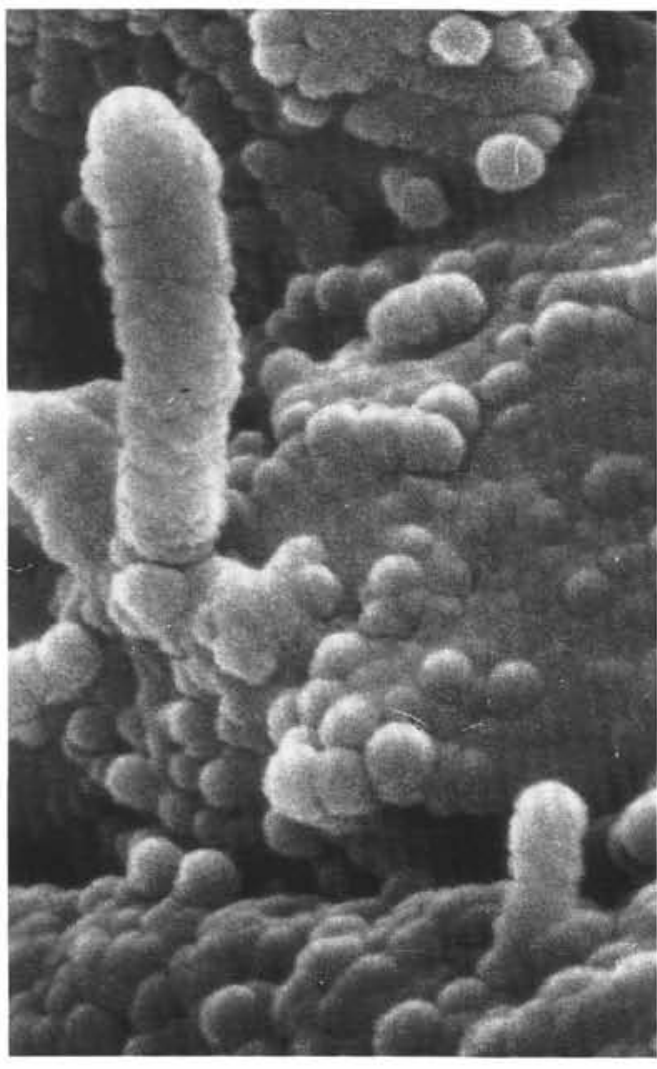

4

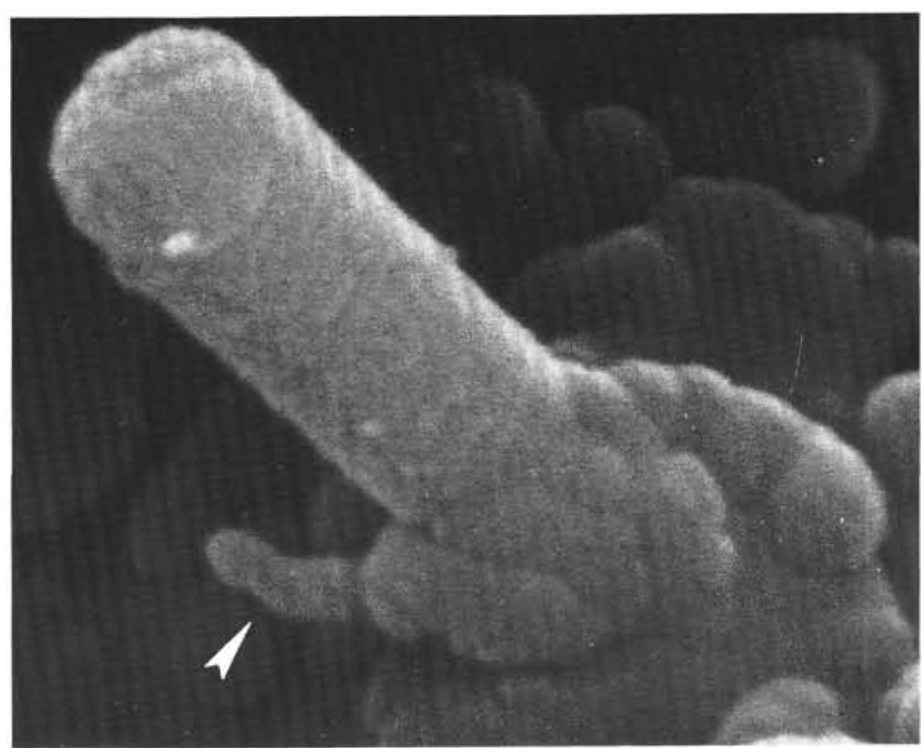

3

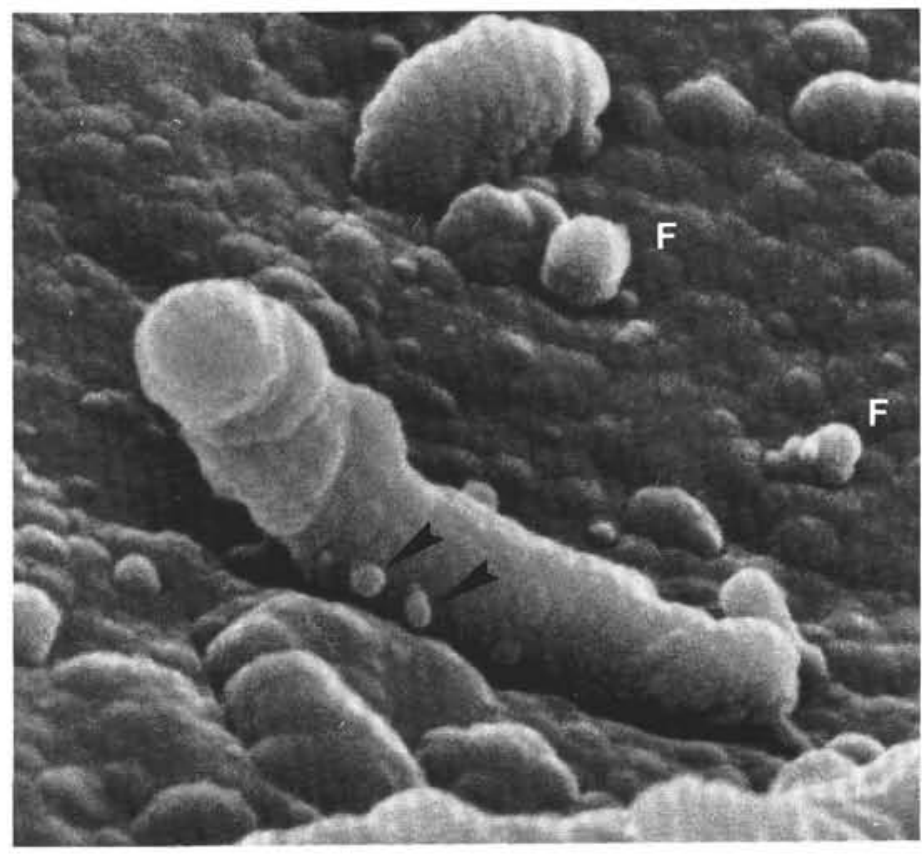

6

Plate 3. Filamentous bacteria. 1. Slightly encrusted filament with lower part resting on a diatom fragment overgrown by microhemispheroids (Sample $114-699 \mathrm{~A}-8 \mathrm{H}-2,108-110 \mathrm{~cm}$ ). Scale $=1 \mu \mathrm{m} .2$. Very small filament and microhemispheroid (Sample 114-699A-8H-2, 108-110 cm). Scale $=0.5 \mu \mathrm{m}$. 3. Short, stubby filament with base encrusted by microhemispheroids. Small epiphylic filament shown at arrow (Sample 114-699A-8H-2, 108-110 $\mathrm{cm})$. Scale bar $=1 \mu \mathrm{m}$. 4. Slightly encrusted filaments on a substrate covered with microhemispheroids exhibiting compromise boundaries. Microhemispheroids partly engulfed by smooth cement (middle right) (Sample 114-699A-10H-1, 92-94 cm). Scale $=1 \mu \mathrm{m}$. 5. Small filament with encrusted, club-shaped head (Sample 114-699A-10H-1, 92-94 cm). Scale $=0.5 \mu \mathrm{m}$. 6. Short, stubby filament with epiphytic bacteria attached to its surface (arrows). Substrate (detrital grain) is overgrown by embedded and draped microhemispheroids in a smooth cement. Heads of filaments $(F)$ protrude out of the cement, and the humpbacked structure in the background could be a filament that has toppled over (Sample 114-699-10H-1,92-94 $\mathrm{cm})$. Scale $=1 \mu \mathrm{m}$. 


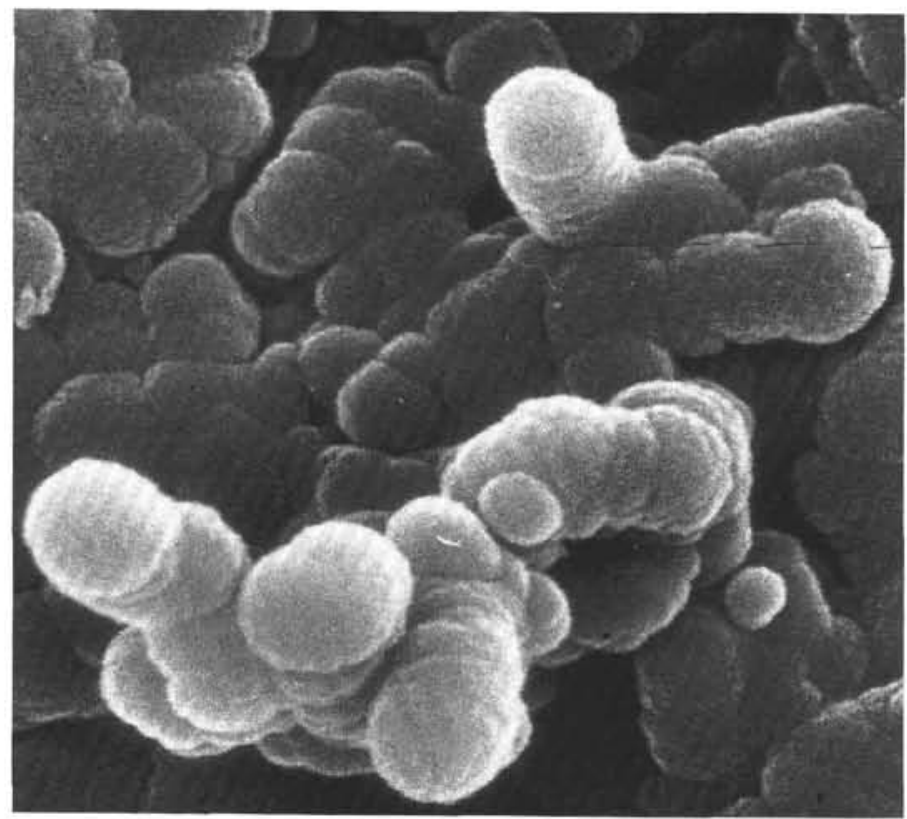

1

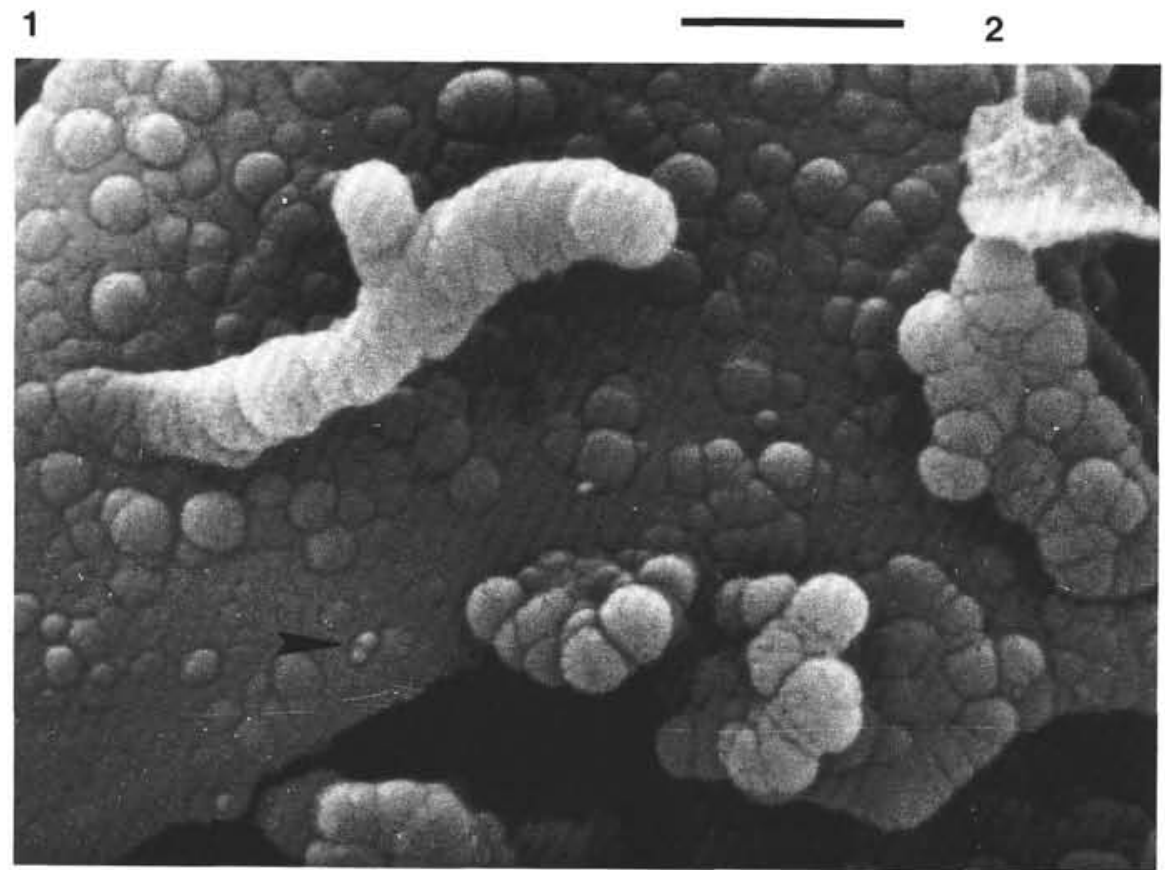

3

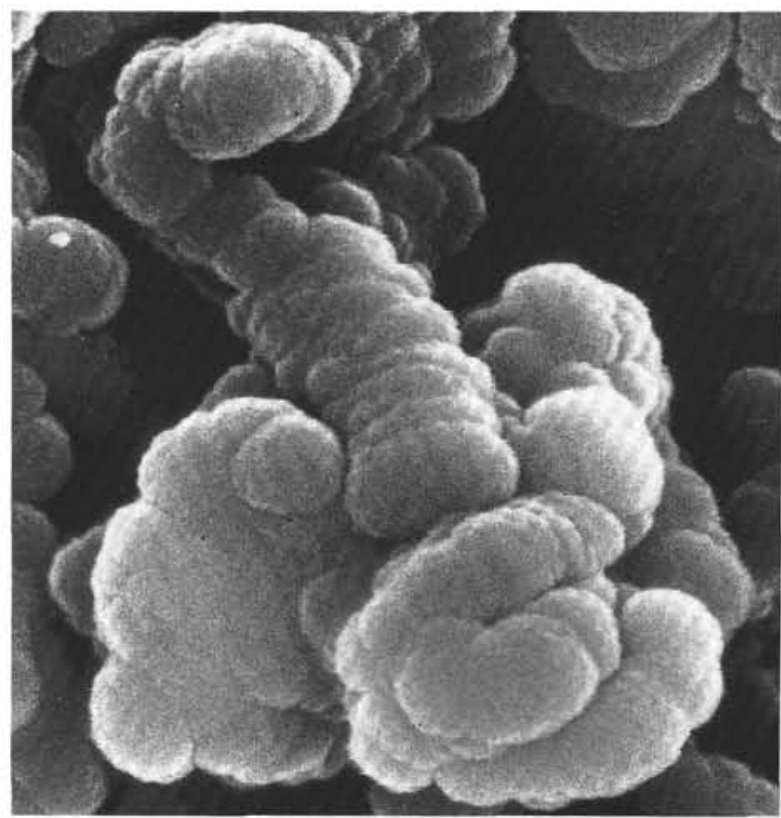

2

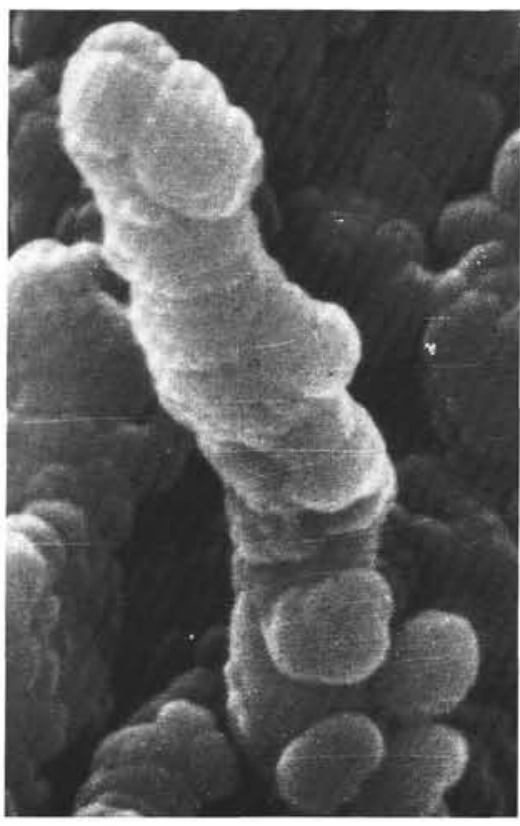

4

Plate 4. Overgrowths on filaments. Scale $=1 \mu \mathrm{m}$. 1. Silica-encrusted filaments growing on top of flaky accretions (Sample 114-699A-8H-2, $108-110 \mathrm{~cm}$ ). 2. Complex overgrowth of filament(s) by microhemispheroids and blobs (Sample 114-699A-8H-2, 108-110 cm). 3. Moderate encrustation. Filament firmly anchored in an overgrown (detrital?) particle. Microhemispheroids showing compromise boundaries are partly embedded in a smooth cement through which hummocks of draped microhemispheroids are visible. Note "moats" around the embedded microhemispheroids and small "budding" microhemispheroid at arrow; see also Plate 7, Figure 2 (Sample 114-699A-10H-1, 92-94 cm). 4. Filament heavily encrusted by microhemispheroids (Sample 114-699A-8H-2, 108-110 cm). 

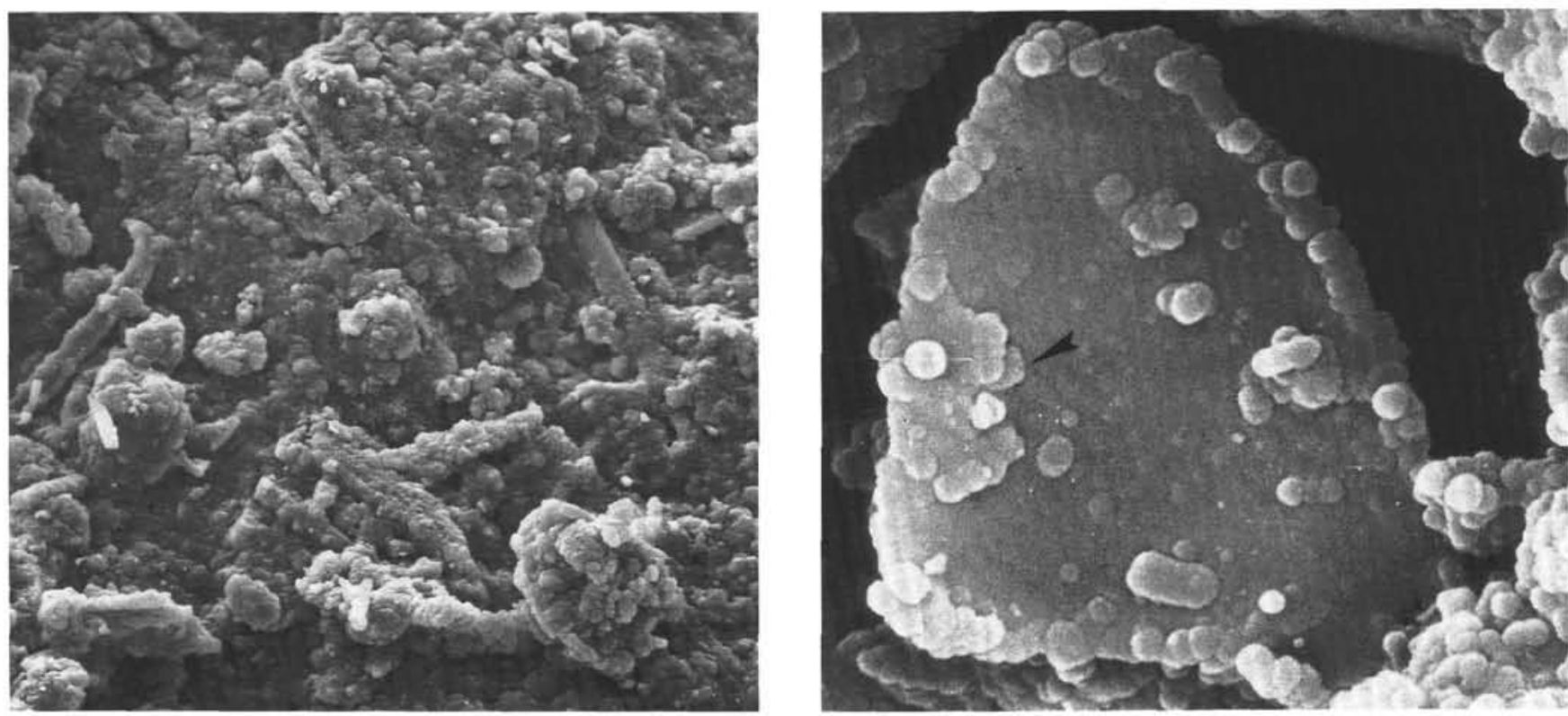

\section{1}

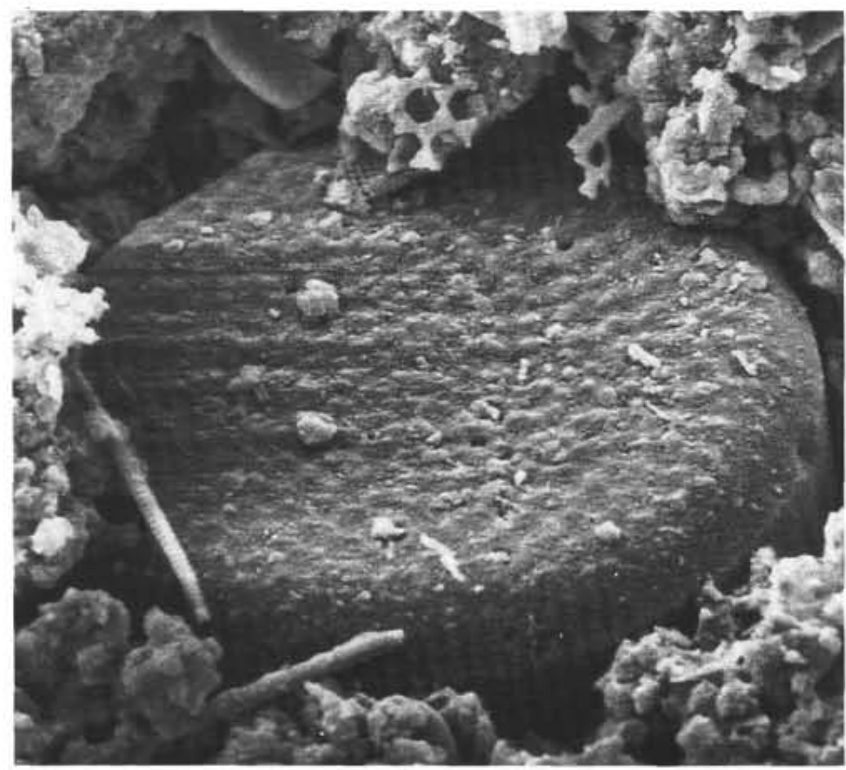

3

\section{2}

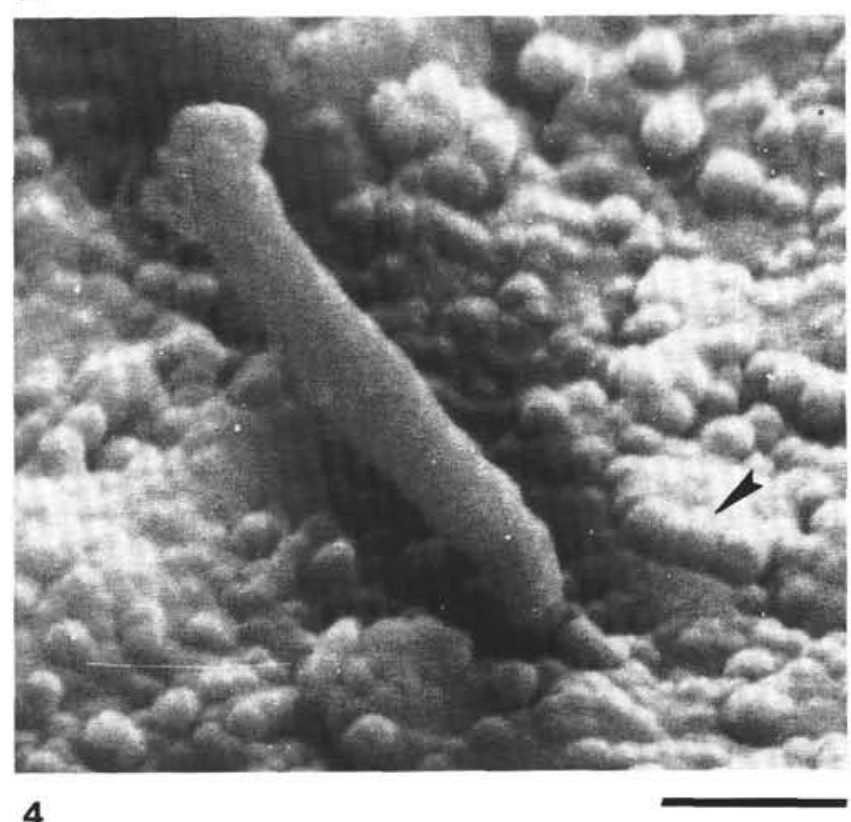

Plate 5. Microhemispheroids. 1. General view showing whole sample overgrown by opaline microhemispheroids (Sample 114-699A-8H-2, $108-110 \mathrm{~cm})$. Scale $=10 \mu \mathrm{m}$. 2. Microhemispheroids preferentially overgrowing the edge of a detrital particle but also colonizing the inner surface. Incipient formation of a flake by coalescing blobs (arrow) (Sample 114-699A-10H-1, 92-94 cm). Scale $=1 \mu \mathrm{m}$. 3. Completely overgrown diatom frustule (Sample 114-699A-10H-1, 92-94 cm). Scale $=1 \mu \mathrm{m}$. 4. Detail of Figure 3 showing overgrowth of microhemispheroids lightly coated with a smooth cement. A filament with slight encrustation on its head is well anchored in the overgrowth. Alignment of microhemispheroids (arrow) (Sample 114-699-10H-1, 92-94 cm). Scale $=1 \mu \mathrm{m}$. 

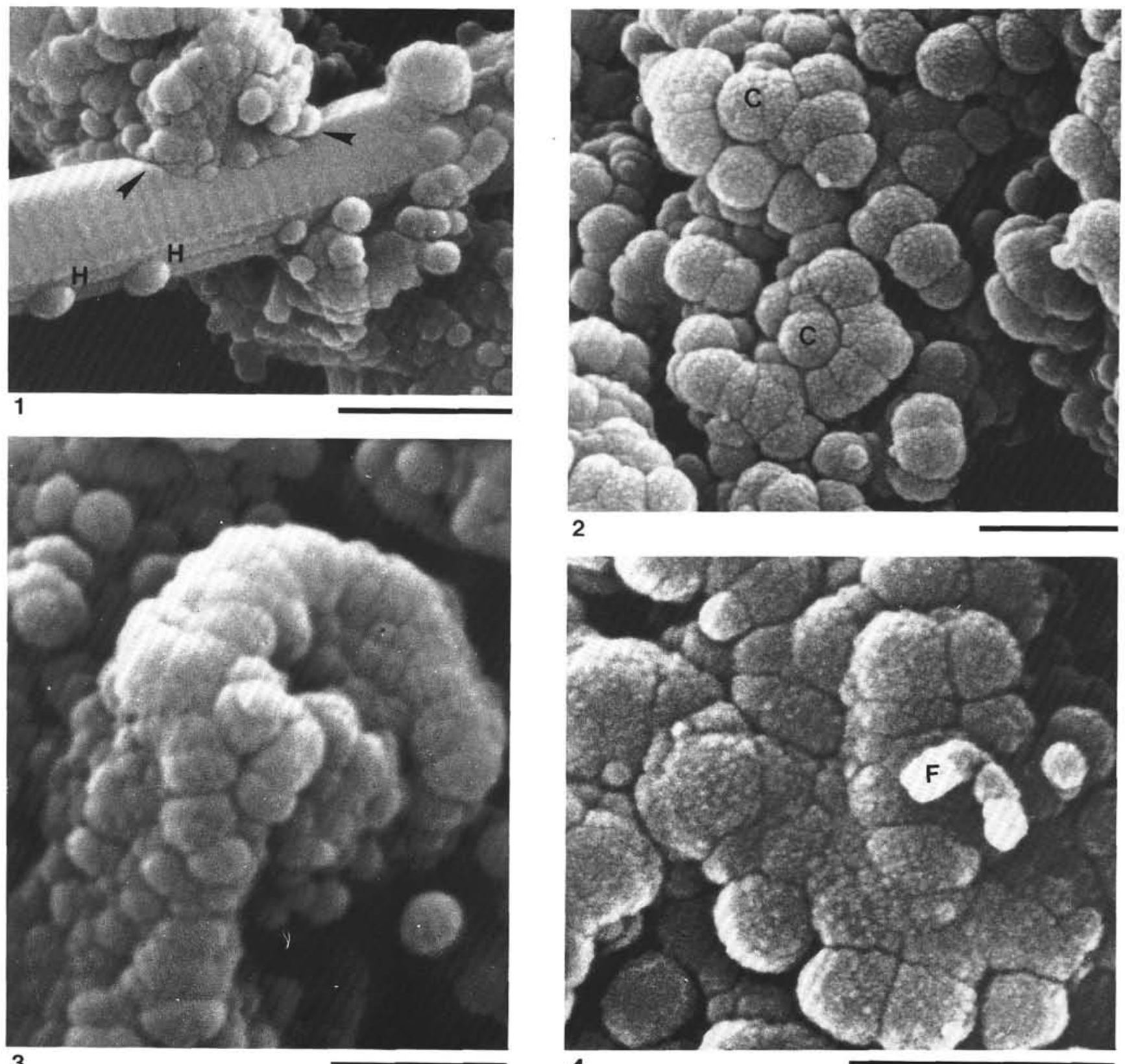

2

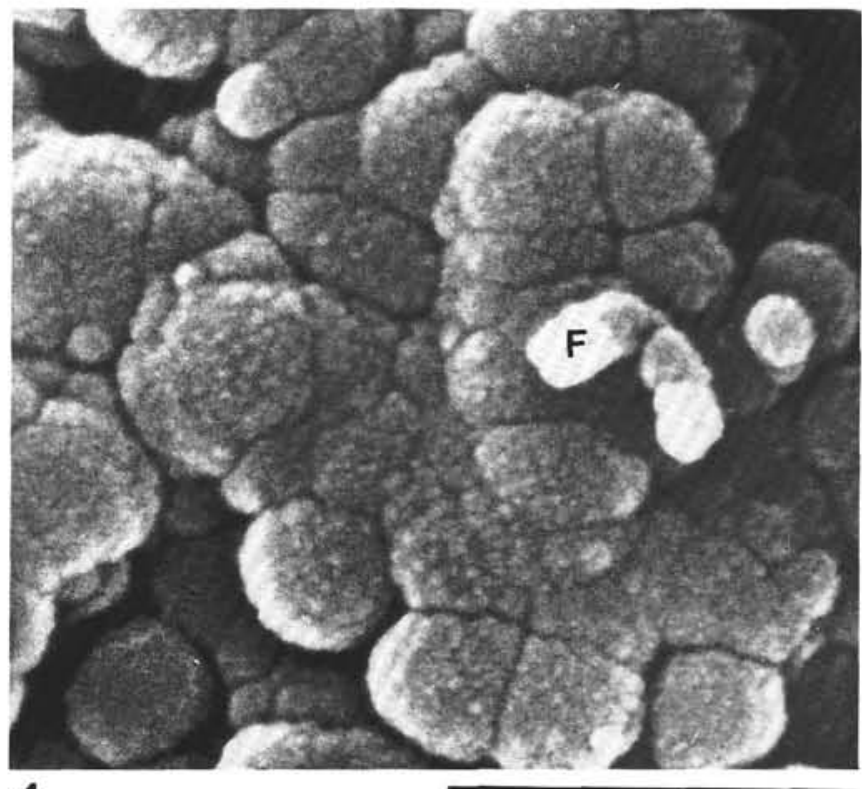
3 4

Plate 6. Microhemispheroids. Scale bar $=1 \mu \mathrm{m}$. 1. Spicule being engulfed by hemispheroids, some of which exhibit perfectly hemispherical shapes $(H)$; arrows at indications of (bio?) corrosion of the spicule in the vicinity of the overgrowth (Sample 114-699A-10H-1, 92-94 cm). 2. Circular arrangement of microhemispheroids around a central hemispheroid $(C)$ (Sample 114-699A-10H-1, 92-94 cm). 3. Leftover encrustation of microhemispheroids after decay of the central filament (Sample 114-699A-10H-1, 92-94 cm). 4. Cubic arrangement of microhemispheroids. Small protruding filament heads $(F)$ (Sample 114-699A-10H-1, 92-94 cm). 


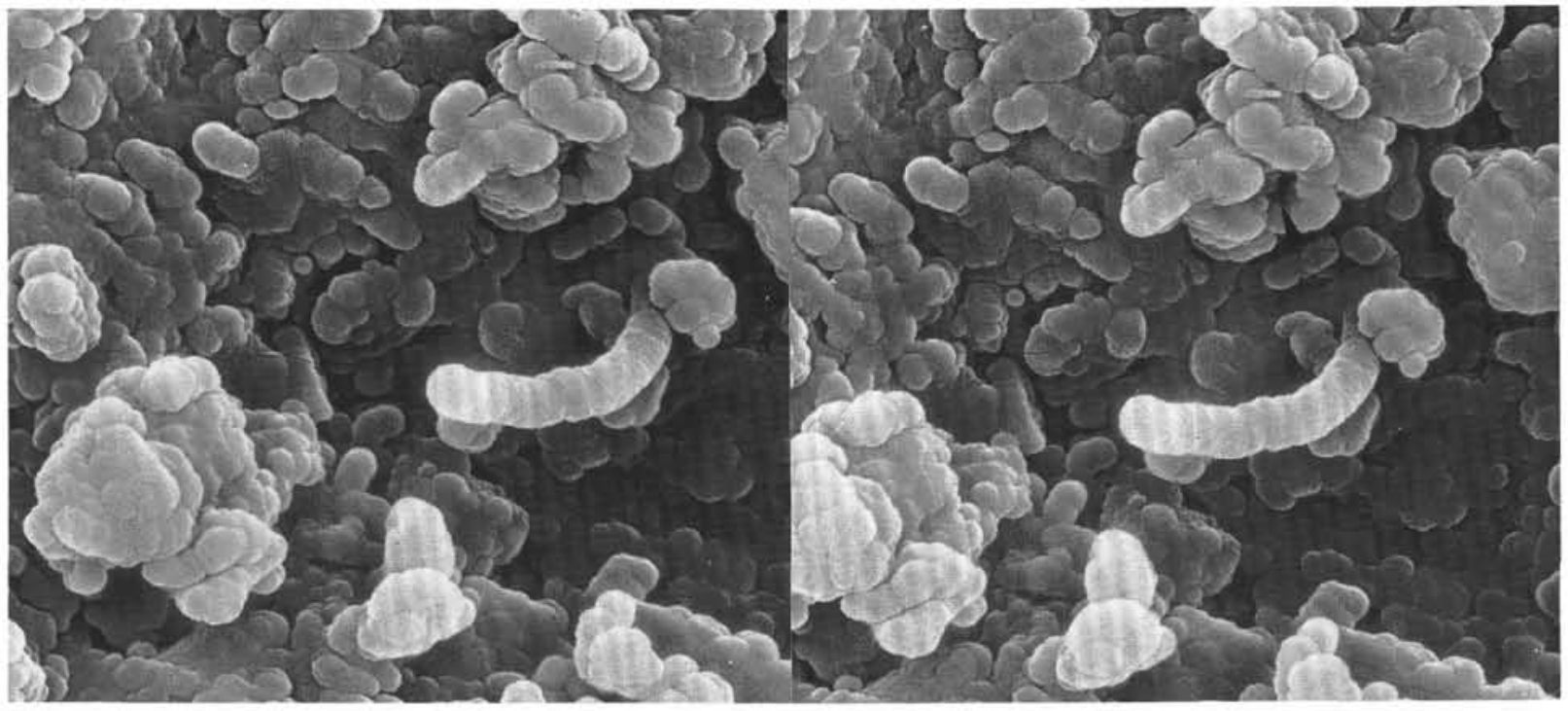

1

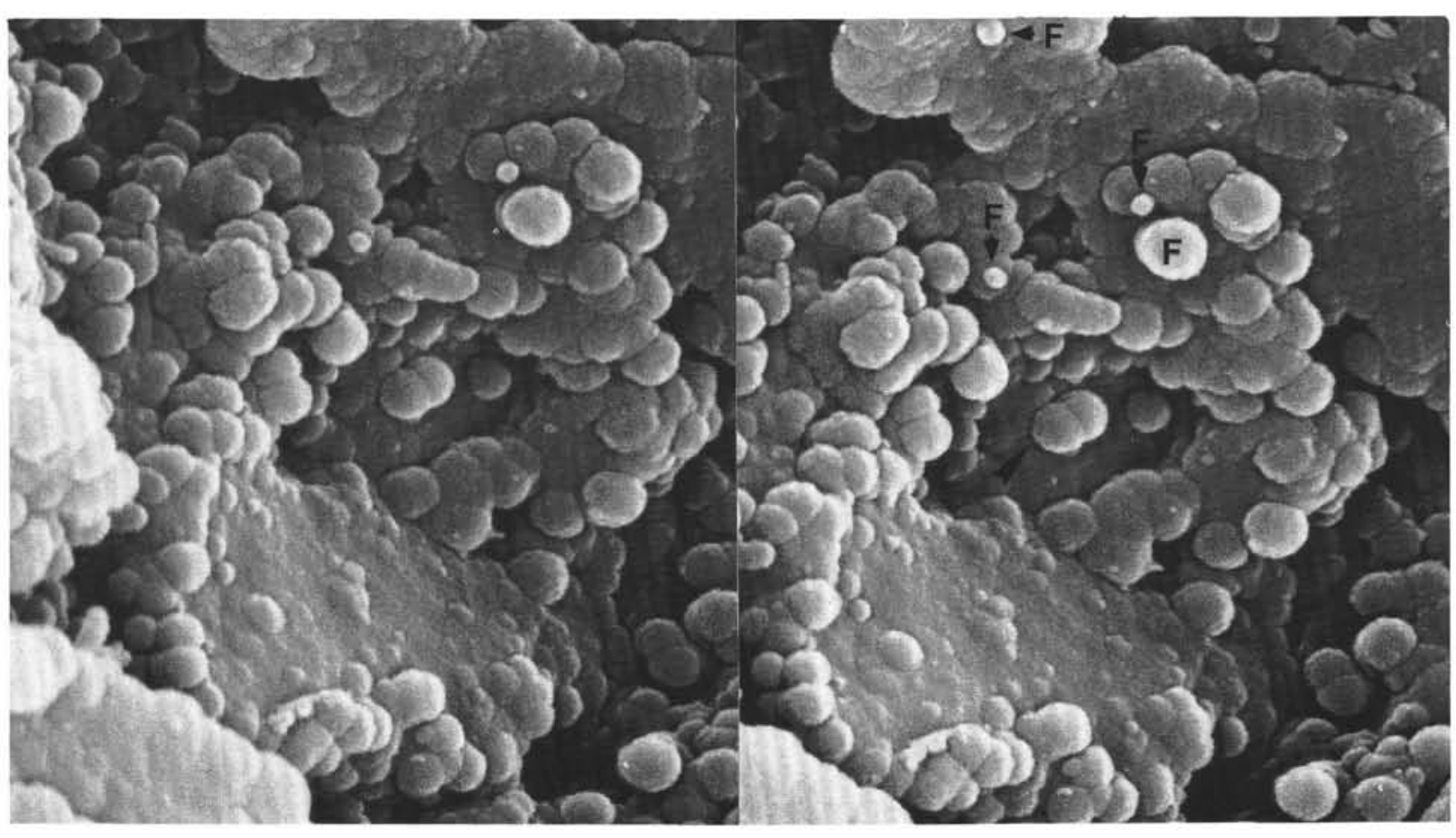

2

Plate 7. Stereopairs. Scale bar $=1 \mu \mathrm{m}$. 1. Segmented filament protruding from a groundmass consisting of coalesced microhemispheres that form fat, globular flakes. Arrows mark an aggregate of microhemispheroids and flakes remaining after filament decay (Sample 114-699A-8H-2, 108-110 cm). 2. Coalesced microhemispheroids in the groundmass and around the edge of a particle on which they are embedded in the surface of and partly draped by a smooth cement. "Budding" microhemispheroid (arrow); head of protruding filaments $(F)$. Heads of numerous small filaments (bright spots $<0.05 \mu \mathrm{m}$ diameter) protrude from the smooth cement coat and through the microhemispheroids (Sample 114-699A-10H-1, 92-94 cm). 


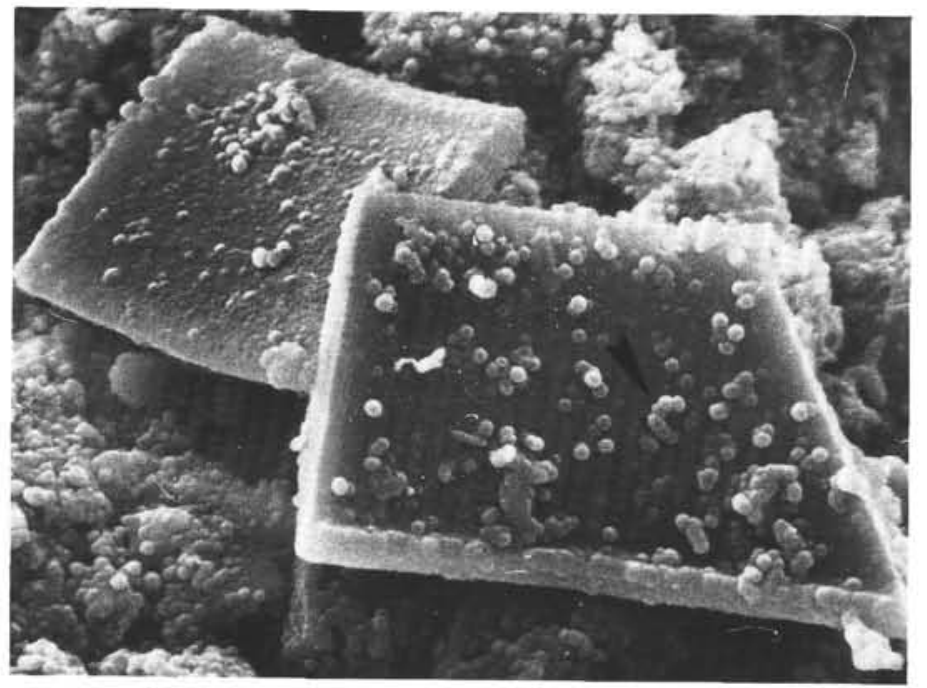

1

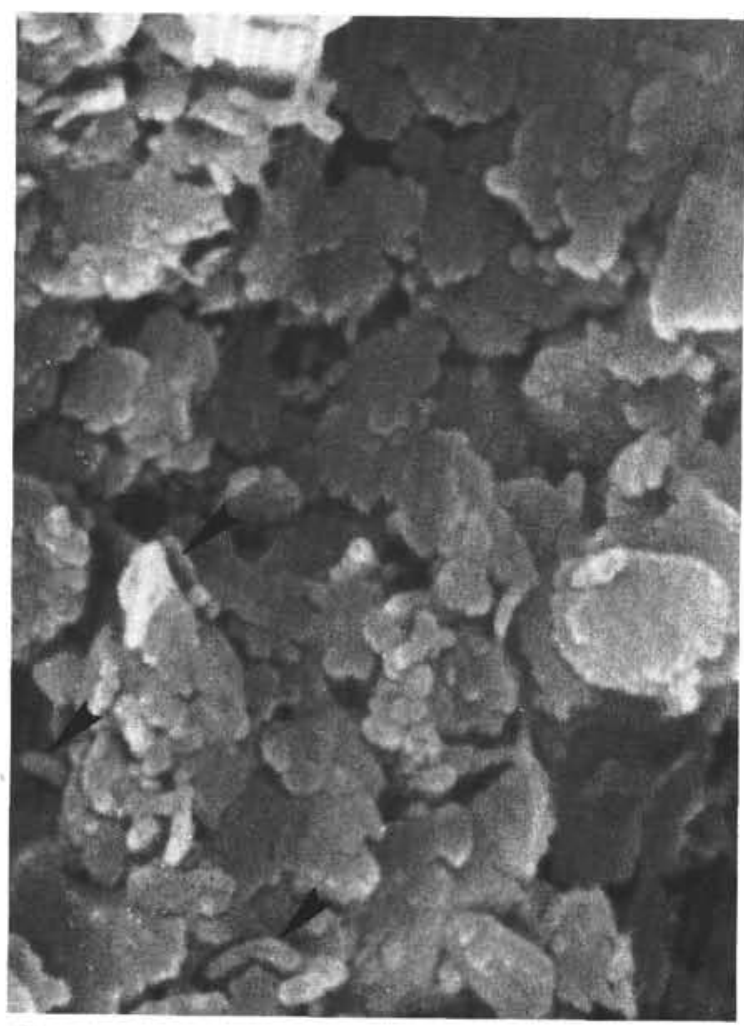

3

4
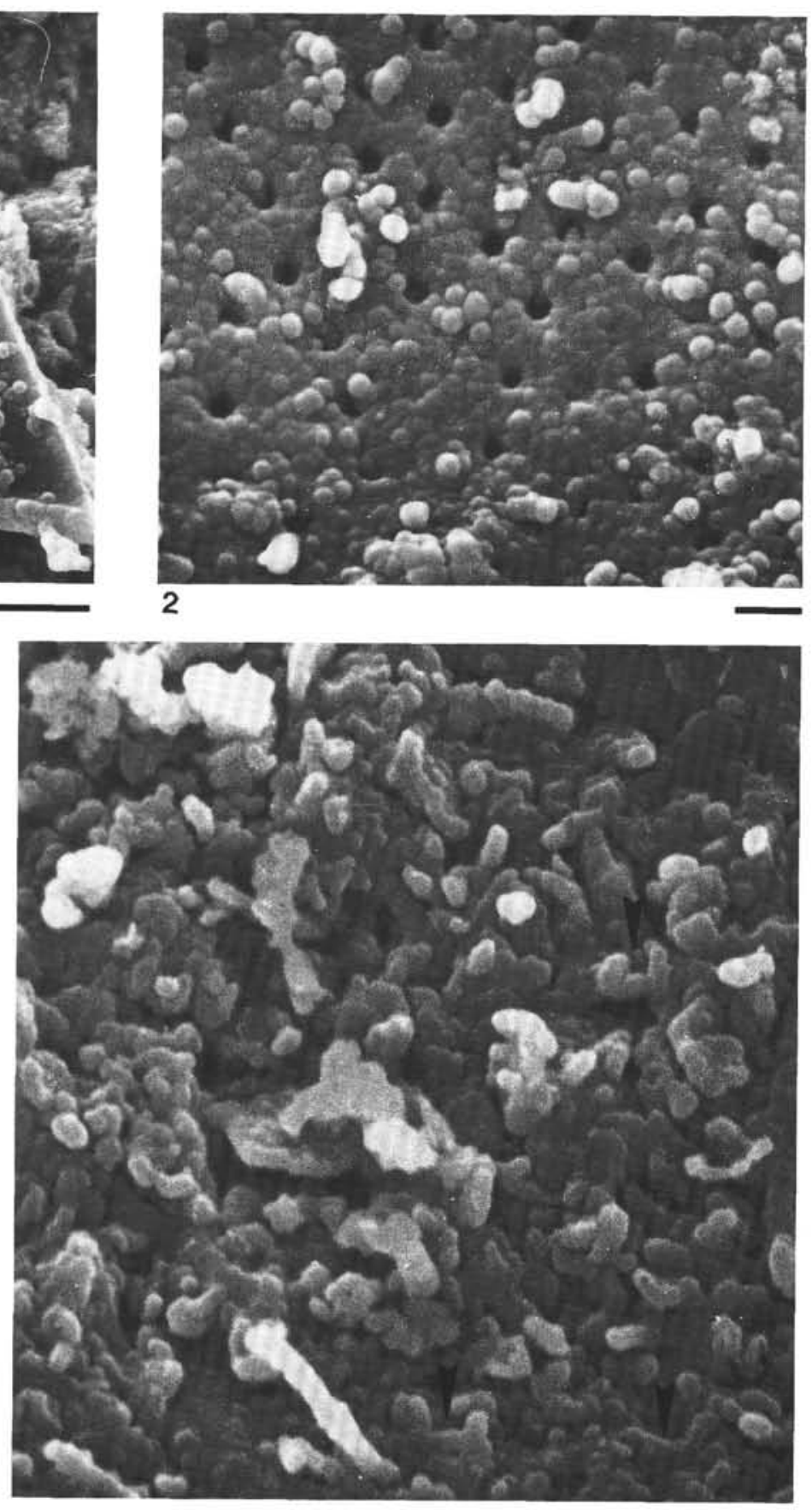

Plate 8. Microhemispheroids and neogenic flakes. 1. Microhemispheroids scattered on the surface of a detrital grain have a locally developed circular arrangement (arrow). Note their distribution along the edge of the grain (Sample 114-699A-10H-1, $92-94 \mathrm{~cm}$ ). Scale $=10 \mu \mathrm{m} .2$. Scattered microhemispheroid overgrowths on a diatom frustule partly occlude the areolae (Sample 114-699A-10H-1, 92-94 cm). Scale = 1 $\mu \mathrm{m}$. 3. Parallel orientation of flakes with serrated edges. Note short, stubby filaments (arrows) (Sample 114-699A-10H-1, 92-94 cm). Scale $=1 \mu \mathrm{m}$. 4. Intergrowth of short, stubby filaments to form an almost flaky groundmass. Angular pattern of intergrowth (arrows). A long, thin filament grows out of the intergrowth at the center bottom (Sample 114-699A-18H-5, 36-38 cm). Scale $=1 \mu \mathrm{m}$. 

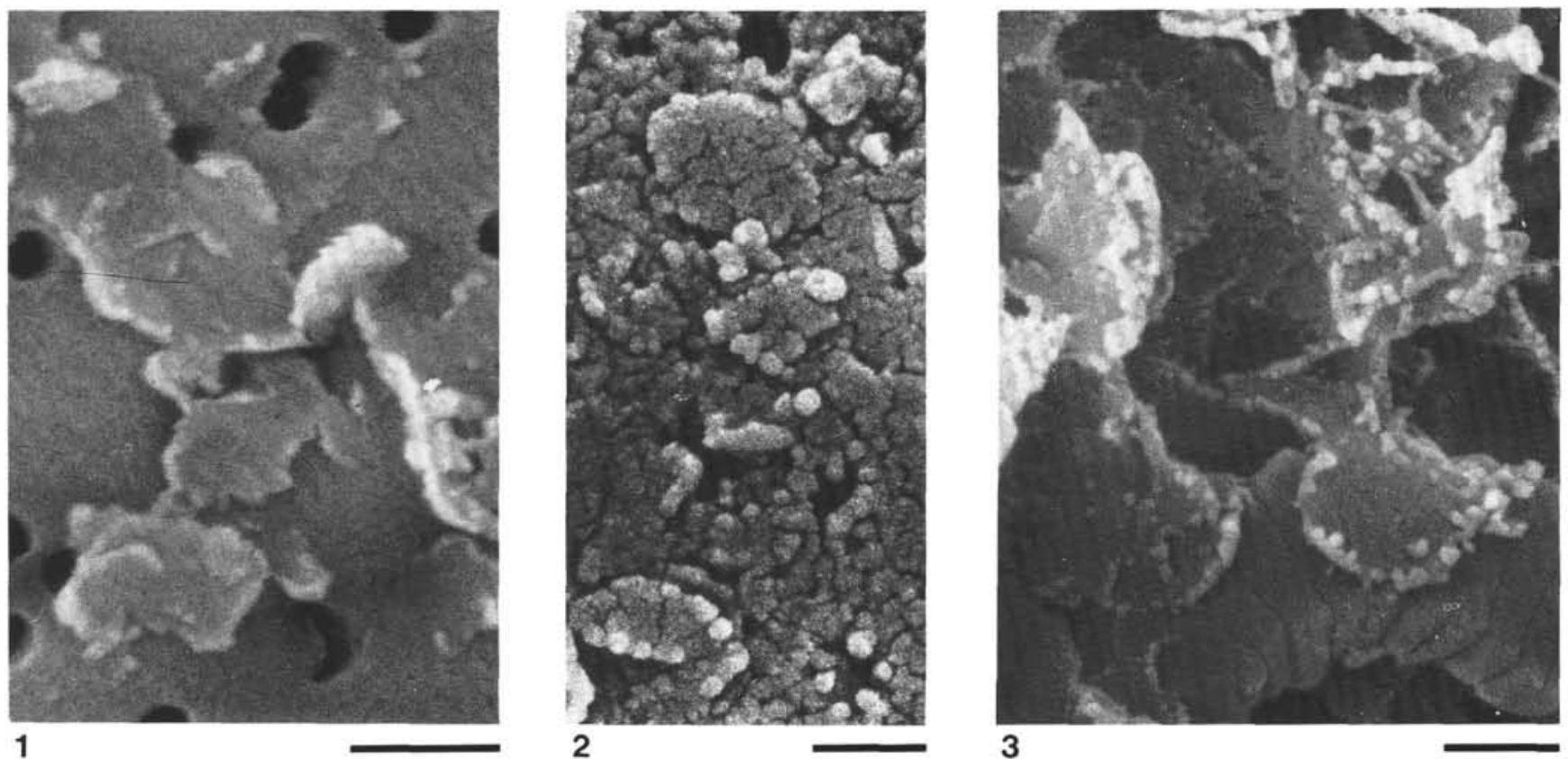

1
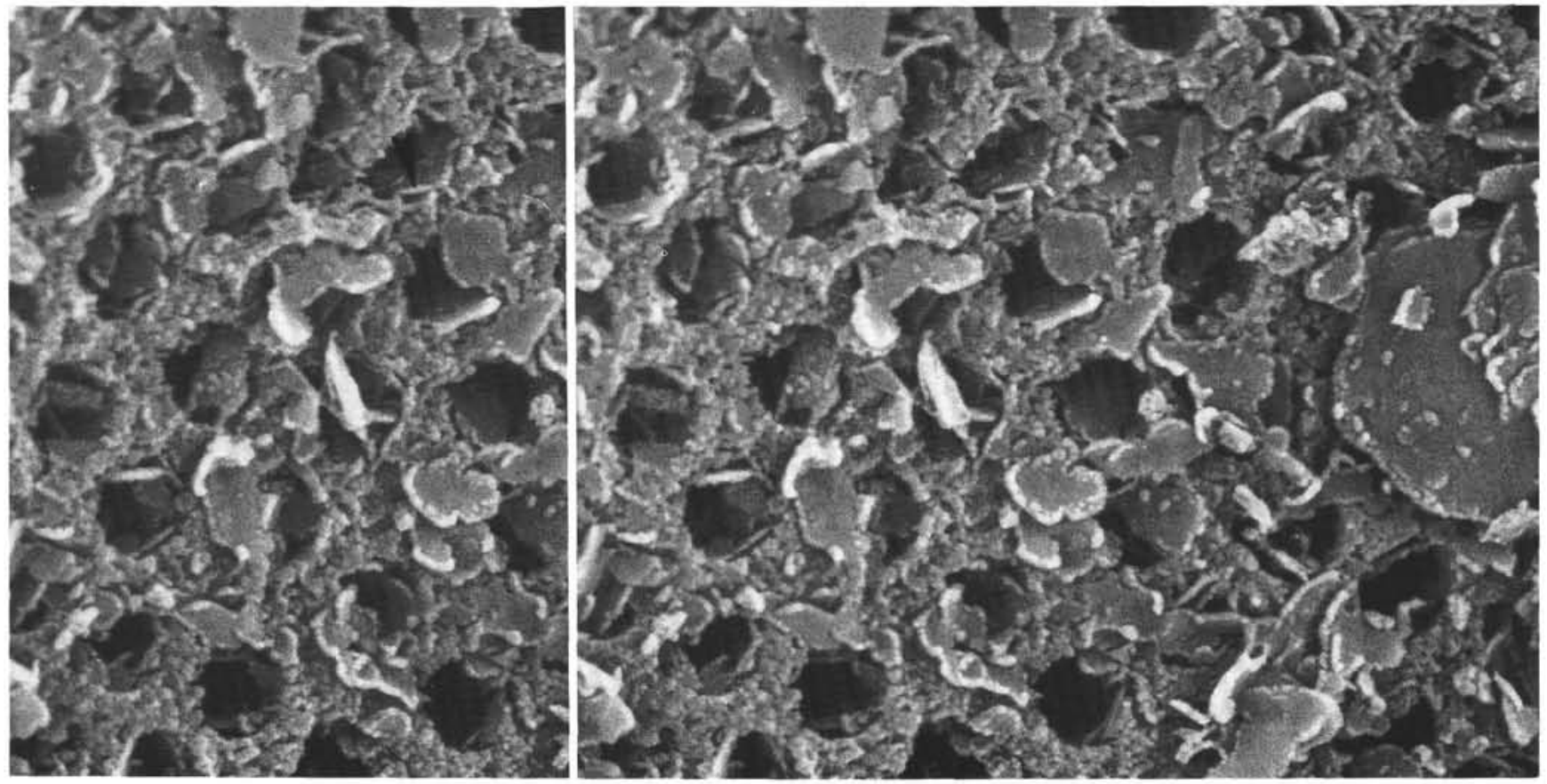

4

Plate 9. Neogenic flakes. 1. Small flakes with curled-up edges growing out of the smooth surface of diatom frustule (Sample 114-699A-5H-5, 7-9 $\mathrm{cm}$ ). Scale $=0.5 \mu \mathrm{m}$. 2. Flakelike structures attached to a highly altered diatom. The flake surface is microfissured (Sample 114-699A-18H-5, 38-38 cm). Scale $=0.5 \mu \mathrm{m}$. 3. Subcircular flakes with microhemispheroids around their edges and a microfissured surface overgrowing a coccolith (Sample 114-699A-10H-1, 92-94 cm). Scale $=0.5 \mu \mathrm{m}$. 4. Stereopair of a highly corroded diatom frustule, partly replaced (arrow) by smooth-surfaced flakes. Flakes on the surface are curled, those in areolae are straight (Sample 114-699A-5H-5, 7-9 cm). Scale $=1 \mu \mathrm{m}$. 

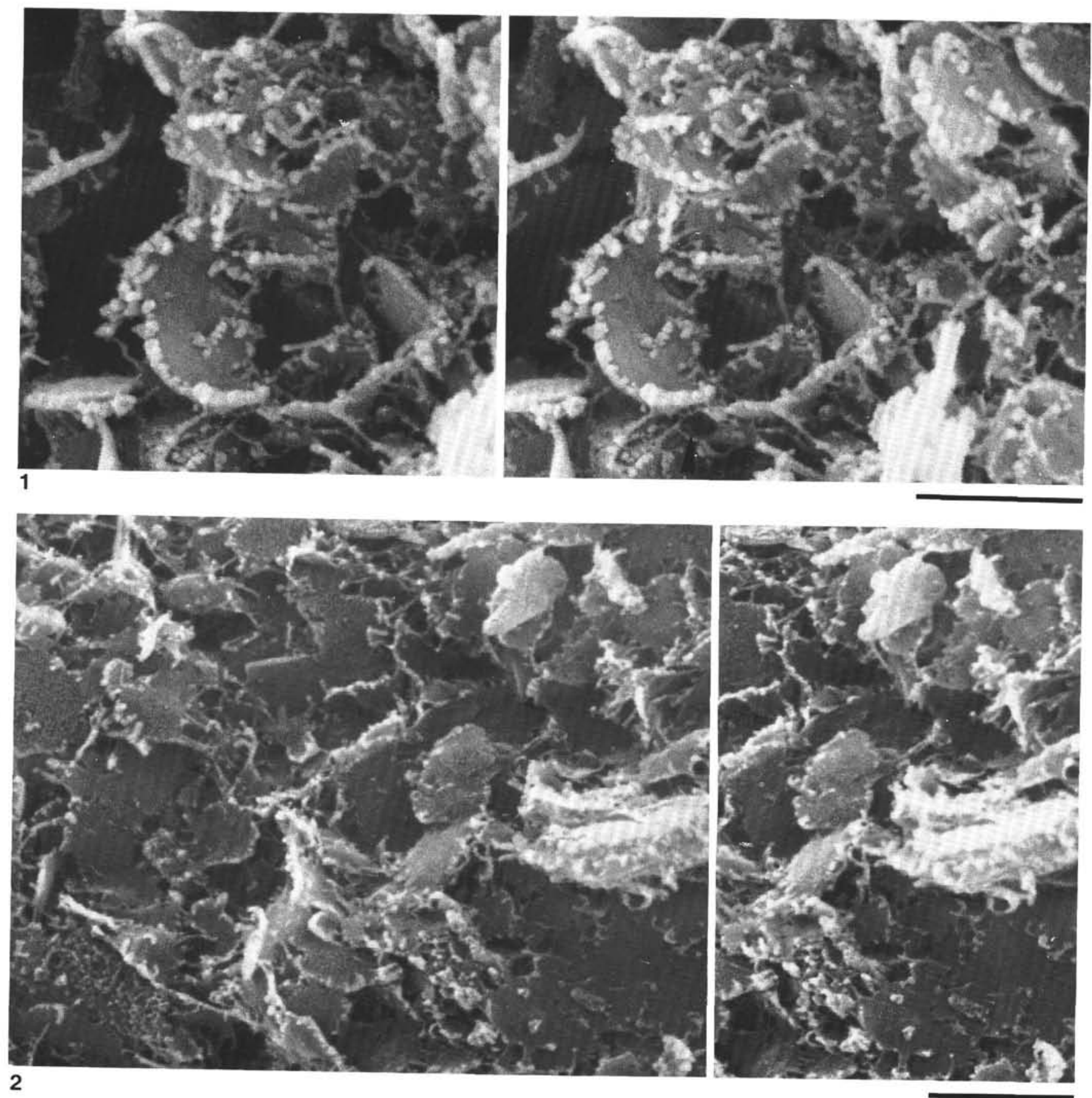

Plate 10. Stereopairs of neogenic flakes. Scale bar $=1 \mu \mathrm{m}$. 1. Left to right: flakes with rolled edges grade into flakes with very fine filaments stretched between them (arrows) (Sample 114-699A-18H-5, 36-38 cm). 2. Smooth-surfaced flakes (possibly smectite) with fibrous edges and a honeycombed structure (Sample 114-699A-10H-1, 92-94 cm). 